\title{
Petrology of the East Pacific Rise Crust and Upper Mantle Exposed in Hess Deep (Eastern Equatorial Pacific)
}

\author{
Roger Hekinian, ${ }^{1}$ Daniel Bideau, ${ }^{1}$ Jean Francheteau, ${ }^{2}$ Jean Louis Cheminee, ${ }^{2}$ Rolando Armijo, ${ }^{2}$ \\ PETER LONSDALE, ${ }^{3}$ AND NORBERT BLUM ${ }^{4}$
}

\begin{abstract}
The Hess Deep, a rifted oval-shaped depression located east of the Galapagos Triple Junction at the tip of the Cocos-Nazca ridge (about $101^{\circ} \mathrm{W}, 2^{\circ} \mathrm{N}$ ), was explored in 1988 during 21 submersible dives. A total of 11 dives were devoted to the exploration of the E-W trending Intrarift ridge (15 km in length, 3000-5400 m in depth) north of the Hess Deep depression. The Intrarift ridge represents an outcrop of recent (1 m.y.) crustal and subcrustal material created at the axis of the East Pacific Rise (EPR), and emplaced during the lithospheric extention responsible for the westward propagation of the Cocos-Nazca rift (Francheteau et al., 1990). The lithospheric block has undergone cataclastic deformation and was dislocated by tectonic activity as attested to by the mixed and erratic distribution of rock types and by the occurrence of polygenic breccias and gabbroic mylonites. The samples are metamorphosed to varying degrees, but their protolith textures are generally well preserved. Their relic mineralogy indicates that they consist of harzburgites, dunites, gabbroic cumulates (gabbronorites and olivine gabbros), isotropic gabbros, dolerites, and basalts. Some samples of refractory harzburgites and most dunitic cumulates (with local accumulation of chromite) have been impregnated by wehrlitic and gabbroic primitive melts similar to those described from the mantle-crust transition zone of the Samail ophiolite complex (Oman). The mineral chemistry indicate that the ultramafics partly reequilibrated with the magmatic impregnations in the liquidus-solidus temperature range of $980-1100^{\circ} \mathrm{C}$. The dolerites and basalts have been derived from mid-ocean ridge basalt primary melts presenting a broad range of incompatible element composition which suggests intermittent cycles of magmatic processes involving a progressive melting of a composite source with discontinous extraction of liquids as proposed for the EPR volcanics near $13^{\circ} \mathrm{N}$ (Hekinian et al., 1989). Most of the rocks underwent partial retrograde metamorphism and recorded several episodes of recrystallization from the upper greenschist facies (ultramafics and gabbros) to diagenetic alteration (volcanics). The cumulate gabbronorites, the isotropic gabbros, and some dolerites were partially albitized and amphibolitized during the penetration of seawater in the ocean crust prior to serpentinization. Several samples of unfoliated amphibolites are believed to be completely metamorphosed gabibroic rocks. The gabbroic cumulates and the plagioclase-rich melt impregnations were variably rodingitized (presence of various $\mathrm{Ca}$-silicates such as epidote, prelunite, hydrogarnet, and zeolite) in relation to the serpentinization of the peridotites. One dive located on the scarps forming the northern wall of the Hess Deep to the east of the explored area, revealed the presence of in situ outcrops of isotropic gabbros, doleritic dikes, and extrusives and permitted to observe the contact between the sheeted dike complex and the high level isotropic gabbros.
\end{abstract}

\section{INTRODUCTION}

The recovery of serpentinized peridotites and gabbroic rocks from the east Pacific fracture zones and rifted regions has been very limited. Deep seated rocks were reported from the East Pacific Rise (EPR) in the Eltanin fracture zone near $55^{\circ} \mathrm{S}$ [Neprochnov and Kashintsev, 1978], in the Garrett transform fault near $13^{\circ} \mathrm{S}$ [Hébert et al., 1983; Cannat et al., 1990; Bideau et al., 1991; Hekinian et al., 1992], and in the Pito Deep near $23^{\circ} \mathrm{S}$ [Constantin et al., 1993]. On the Galapagos spreading center, other occurrences of gabbros, serpentinites and mafic breccia were found in the equator fracture zone near $85^{\circ} \mathrm{W}$ [Anderson and Nishimori, 1979] and in the Hess Deep near $101^{\circ} \mathrm{W}$ [Neprochnov and Kashintsev, 1978; Rudnik, 1976; Francheteau et al., 1990]. Similar deep seated rocks were also sampled from the Galapagos fossil rise near $16^{\circ} \mathrm{S}$ on the Cocos plate [Anderson and Nishimori, 1979], and from the Mathematician ridge near $17^{\circ} \mathrm{N}$ on the Pacific plate between the Clarion and the Clipperton fracture zones [Vanko and Batiza, 1982]. In addition, a few examples of gabbroic inclusions

\footnotetext{
${ }^{1}$ IFREMER/Centre Brest, Plouzané, France.

${ }^{2}$ Institut de Physique du Globe, Paris, France.

${ }^{3}$ Scripps Institution of Oceanography, La Jolla, California.

${ }^{4}$ Institut für Petrographie und Geochemie der Unversität Karlsruhe, Karlsruhe, Germany.
}

Copyright 1993 by the American Geophysical Union. (xenoliths) carried up to the surface by tholeiitic flows and exposed on the axial graben of the EPR (i.e., near $12^{\circ} 50 \mathrm{~N}$ and $18^{\circ} 30^{\prime}$ S) were reported by Hekinian et al. [1985] and Hekinian and Bideau [1986].

The structure of the Hess Deep results from the rifting of an ocean crust created about 1 m.y. ago at the adjacent fast spreading (13 to $13.5 \mathrm{~cm} / \mathrm{yr}$ ) EPR axis [Searle and Francheteau, 1986; Lonsdale, 1988; Francheteau et al., 1990]. The geological setting of the explored area is characterized by an uplift of the lower crust and the mantle/crust transitional zone associated with a volcanically starved segment of the Cocos-Nazca ridge propagator [Franchetean et al., 1990]. Upper crustal levels with dike-gabbro transition zones are also exposed on the rift walls. The only similar situation in the world's ocean is that of the Pito Deep, a depression (5850 $\mathrm{m}$ depth) located at the tip of the Easter propagator, on the Easter microplate near $23^{\circ} 29^{\prime} \mathrm{S}$ $111^{\circ} 56^{\prime} \mathrm{W}$ and close to the EPR axis [Francheteau, et al., 1988]. Dredges and a deep towed television run, carried out on the eastern wall of the Pito Deep by the R/V Sonne (leg SO65, 1989), revealed the presence of sedimented slopes on which large gabbroic blocs and dolerites occur.

Previous work on the Hess Deep reported the exposure of lower crust and upper mantle rocks [Rudnik, 1976; Neprochnov and Kashintsev, 1978; Kashintsev et al., 1982]. Hydrothermal serpentine in sandy sediments [Rozanova et al., 1979; Murdmaa and Rozanova, 1976; Schmitz et al., 1982] were dredged and cored with little knowledge about the geological setting from which they came. In 1988, the NAZCOPAC (Nazca Cocos Pacifique) cruise was carried out in the Hess Deep with the submersible Nautile (IFREMER, Institut Français de Recherche 
pour l'Exploitation de la Mer) and its support ship, the $R / V$ Nadir:

The dives permitted us to have access to a detailed structural and lithological record of the upper mantle and crust material emplaced during a lithospheric extension conjugated with an uplift [Francheteau et al., 1990]. The present work deals primarily with the igneous petrology in relation to the geological setting of the rocks sampled from the walls and the top of the Intrarift ridge located at the margin of the Hess Deep and the Cocos-Nazca ridge near $101^{\circ} 30^{\prime} \mathrm{W}-2^{\circ} 15^{\prime} \mathrm{N}$ (Figures $1 \mathrm{a}$ and $1 \mathrm{~b}$ ). Samples from further north on the Intrarift ridge near $101^{\circ} 15^{\prime} \mathrm{W}$ $2^{\circ} 25^{\prime} \mathrm{N}$ (dive 20 ) were also included in this study because they represent a section of upper crust with in situ outcrops showing contact between doleritic dikes and gabbros. In addition, a comparative study between the volcanics found on the Intra-rift ridge along with the EPR mid-ocean ridge basalts (MORBs) and the samples from the active Cocos-Nazca ridge is presented. The large diversity of the igneous rocks recovered from the Hess Deep makes this collection of oceanic crust and upper mantle rocks one of the most complete today.

\section{Geological Settings}

The Intrarift ridge of the Hess Deep is about $8 \mathrm{~km}$ wide and 25 $\mathrm{km}$ long, and it is oriented E-W, parallel to the Cocos-Nazca axial ridge [Francheteau et al., 1990]. Three dome-shaped summits culminating between $2900 \mathrm{~m}$ and $3000 \mathrm{~m}$ depth are recognized along its crest from the Sea Beam bathymetric data published by Lonsdale [1988]. During the diving cruise only about half of the western Intra-rift ridge was explored (11 dives) between the Hess Deep at $2^{\circ} 14.25^{\prime} \mathrm{N}-101^{\circ} 33^{\prime} \mathrm{W}$ and the CocosNazca axial ridge at $2^{\circ} 14^{\prime} \mathrm{N}-101^{\circ} 25.50^{\prime} \mathrm{W}$ at depths between 2900 and $5400 \mathrm{~m}$ (Figures $1 a, 1 b, 2$, and 3).

The north facing flank of the Intrarift ridge slopes gently down to about 3750 and $4400 \mathrm{~m}$ and is bounded by an E-W major fault scarp [Lonsdale, 1988] which probably coincides with the northern limit of the dike complex north of the Hess Deep (Figure 1). Dives 10,16, and 21, located on the northern flank of the Intrarift ridge, have revealed the common occurrence of dolerites and basalts (Table 1 and Figures 1b, 2, and 3) which mainly form talus material between $3250 \mathrm{~m}$ and $4000 \mathrm{~m}$ depths (dives 16 and 21). Isotropic gabbros were observed (dive10) near the top of the Intra-rift ridge at 3000 and $3300 \mathrm{~m}$ depth (Figures 1 and 2 and Table 1). The first sample of cumulate gabbro (sample 10-9) on the northern slope was from a large block outcropping at $3468 \mathrm{~m}$ depth and vertical dikes were seen (dive 21) between 3300 and $3600 \mathrm{~m}$ and at $3200 \mathrm{~m}$ further to the east (Figure $1 \mathrm{~b}$ and Table 1). A sample of massive (nonfoliated) amphibolitized gabbro (10-14) was also recovered on this northern flank at $3286 \mathrm{~m}$ depth (Table 1). See Tables A1-A6 available with entire article on microfiche. ${ }^{1}$

The summit area (2900-3100 $\mathrm{m}$ depth) of the Intrarift ridge observed during four dives (Figures $1 b, 2$, and 3 ) exhibits considerable amounts of basaltic breccia and pillow-lava debris (Table 1; samples 21-11, 21-12, 17-19, 16-20, 16-21 and 10-18). An extended field of inactive hydrothermal deposits (16-11 to 16-18) forming a mound of several hundred meters in length and $10-20 \mathrm{~m}$ in height occurs near the top (3000-3100 $\mathrm{m}$ depths) of the Intrarift ridge (Table 1). This deposit essentially consists of

\footnotetext{
${ }^{1}$ Tables A1-A6 are available with entire article on microfiche. Order from American Geophysical Union, 2000 Florida Avenue, N.W., Washington, DC 20009. Document B92-003; \$2.50. Payment must accompany order.
}

Fe-oxyhydroxide crust made up of gocthitc and amorphous material.

A complete crosssection of the southern flank of the Intrarift ridge from the top $(2900 \mathrm{~m})$ down to the bottom of the Hess Deep (5454 m) was surveyed during seven dives located within a $2 \mathrm{~km}$-wide and about $8 \mathrm{~km}$-long (N-S) band (Figures $1 \mathrm{~b}$ and 2). The oval-shaped depression (Hess Deep) at the foot of this south flank is completely covered by sediment and occasional debris of basalts and dolerites. Abundant sediment-free talus occur on the slope at depths between 5442 and $5374 \mathrm{~m}$ (1-4 to 1-6 and 9-3) and extend in a patchy fashion along several levels between 5370 $\mathrm{m}$ and $4600 \mathrm{~m}$ depths along the south flank [Franchetean et al.. 1990] (Figures 2 and 3). This talus material (Table 1 and Figures 2 and 3) consists of unsorted boulders of basalts, mainly pillow lava fragments (2-6), basaltic breccias (18-8), prismatic dolerites (18-1, 18-2, and 18-5), fine- to medium-grained isotropic gabbros, coarse-grained gabbroic cumulates (1-4 and 1-6), metagabbros (1-5), and serpentinized ultramafics containing variable amounts of plagioclase (9-7, 9-8 and 9-9). Isolated blocks a few meters wide (1 to $10 \mathrm{~m}$ ) and several meters high (5$20 \mathrm{~m}$ ) of cumulate gabbros (1-8, 1-9, and 2-2) occur between 5050 and $4720 \mathrm{~m}$ depth (Figures 2 and Table 1 ). In the vicinities of these large gabbroic blocks ( $>5 \mathrm{~m}$ in diameter), other doleritic outcrops (2-4) were also sampled (Figure 2). These large massive and prismatic blocks standing out from the surrounding sediment do not show any preferential orientation. Above 4500 $\mathrm{m}$ depth, along the profiles of dives 8,18 , and 2 , we observed small scarps ( $<5 \mathrm{~m}$ in height) showing flat and disrupted ledges of prismatic, pavement like doleritic rocks which are probably sills, about 10-20 cm thick (samples 2-8, 2-10, and 18-10) (Figures $1 b$ and 2). Outcrops of mylonitic breccias (18-7) and gabbro mylonites (18-9) occur between $4470 \mathrm{~m}$ and $4840 \mathrm{~m}$ near the ledges of prismatic dolerite outcrops (Figure 3 ) together with brecciated material containing hyaloclasites (18-8) and metadolerites (18-10). A gabbro mylonite was also recovered near the summit of the Intrarift ridge (5-7) at a depth of $3157 \mathrm{~m}$ (Figure 2 and Table 1). Cataclastic breccia made up of metagabbros (10-13), serpentinite (17-12), and mylonitic gabbros (10-11, 1-5, 9-20, 18-7, and 18-9) were collected at various depths between 5400 and $3100 \mathrm{~m}$ on the north and south facing flanks of the Intra-rift ridge (Figure $1 b$ and Table 1). Although some of these deformed and recrystallized rocks are found among talus debris, others $(9-20,18-9$, and 17-12) are associated with foliated and faulted outcrops (Table 1). Along the southern flank of the Intrarift ridge at least two areas with low temperature hydrothermal precipitates consisting of $\mathrm{Fe}-\mathrm{Si}$ oxylhydroxide coated with thin Fe-Mn crusts (18-12) were observed at $4400 \mathrm{~m}$ depth (Table 1 and Figure 3). Unsampled soft variegated layers (5-10 cm thick) of white, ochre, and light green hydrothermal products are exposed at $4800 \mathrm{~m}$ depth (dive 8) located less than $500 \mathrm{~m}$ west of the previous area (Figure 3). Farther to the east at about $8 \mathrm{~km}$ from the western cross section, dive 17 along the southern flank of the Intrarift ridge mainly revealed the occurrence of several large blocks and unsorted talus (boulder size) of serpentinite $(17-1,17-2,17-3,17-8,17-10,17-14$, and 17-16) between $4453 \mathrm{~m}$ and $3632 \mathrm{~m}$ depth (Figures 2 and 3). Cumulate gabbros and plagioclase-dunites were also found at shallower depths between $4100 \mathrm{~m}$ and $3500 \mathrm{~m}$ along the same profile (Table 1 and Figure 3).

\section{Anal ytical Procedures}

The electron microprobe analyses were obtained using a Camebax MBX instrument (CAMEBAX de l'Ouest, at 
IFREMER, Centre de Brest, France) in conjunction with a standard correction program for oxides and silicates. The operating conditions were $15 \mathrm{kV}$ accelerating potential, $15 \mathrm{nA}$ specimen current, $6 \mathrm{~s} /$ cycle counting time and focussing on a 1-3 $\mathrm{m}$ spot size. A special program was also used in order to increase the accuracy of the results for $\mathrm{NiO}$ in olivine, $\mathrm{Cr}_{2} \mathrm{O}_{3}$ and $\mathrm{TiO}_{2}$ in pyroxenes, and $\mathrm{TiO}_{2}$ in spinels. The operating conditions were $25 \mathrm{kV}$ accelating potential, $80 \mathrm{nA}$ sample current, and $25 \mathrm{~s} /$ cycle counting time. The mineral compositions are compared to those from the Garrett Transform Fault [Hébert et al., 1983; Cannat et al., 1990] because the rock types are similar and were analyzed with the same laboratory techniques. The bulk rock analyses (Table 2) were performed by an automated $X$ ray fluorescence (Philips PW 1450) at the geochemistry department of the University of Karlsruhe (Germany) by N. Blum.

\section{Mantle and CRustal Rock Assemblages}

Because of the lack of clear primary lithological relationships on the field, the rock types were tentatively sorted according to their pseudo-stratigraphic order (Figure 4) in reference to their normal level of occurrence in ophiolitic complexes (i.e., Samail ophiolite in Oman [Pallister and Hopson, 1981; Nicolas et al., 1988; Juteau et al., 1988]). The samples were classified according to their protoliths whenever they could be identified from their preserved primary textures and mineral assemblages. However, completely metamorphosed samples (i.e., rodingitized or amphibolitized gabbros) were grouped together (metagabbros) without any particular reference to their inferred initial lithological unit.

\section{Ultramafic Rocks}

The ultramafics (harzburgites and dunites) some of which are impregnated and contain abundant plagioclase and/or clinopyroxene (wehrlites and gabbros). Their degree of serpentinization varies among samples and within a single specimen (i.e., sample 17-10; Plates $1 a, 1 b$ and $1 c)$.

Harzburgites. The harzburgites are the most common ultramafics encountered, mainly on the southern flank of the Intrarift ridge along dive track 17 (Table 1, and Figures 2 and 3). They consist of serpentinized olivine and bastitized orthopyroxenes; however, large portions of the original samples are generally preserved (Table 1 and Plate $1 a$ ). Several samples (17-9, 17-10, and 17-12) exhibit a broad foliation outlined by elongated lenses of pyroxene, bastite pseudomorphs and veins of chrysotile (Plate $1 b$ ). The most altered specimens are friable pale yellow to orange coloured rocks (i.e., 17-5 and 17-10) with veins of Fe-oxyhydroxide and aragonite (Plate la). This material ressembles the sticky, pale yellow sediment having a talcose appearence which was commonly encountered along several dive tracks $(1,2,5,17$, and 18) on the Intrarift ridge. The darker specimens of serpentinized harzburgites (i.e., part of samples 178 and 17-9) preserved elongated lenses of olivine and orthopyroxene with clinopyroxene exsolution lamellae (Platelb and $1 c$ ), and have undergone less than $60 \%$ serpentinization. The primary mineral assemblages are weakly deformed and the freshest portions of the rocks exhibit porphyroclastic textures. Olivine relics $\left(\mathrm{Fo}_{84-93}\right)$ often occur in the cores of the serpentine mesh-texture. The freshest part of the samples containing large amounts of olivine porphyroclasts shows scarce kink bands (Plate 2a). One specimen of harzburgite (sample 17-9) shows textural evidences of melt impregnation (Plates $1 b$ and $2 b$ ). The wehrlitic (impregnated) areas contain amoeboid grains of clinopyroxene and rare $(<1 \%)$ prehnitized plagioclase, while

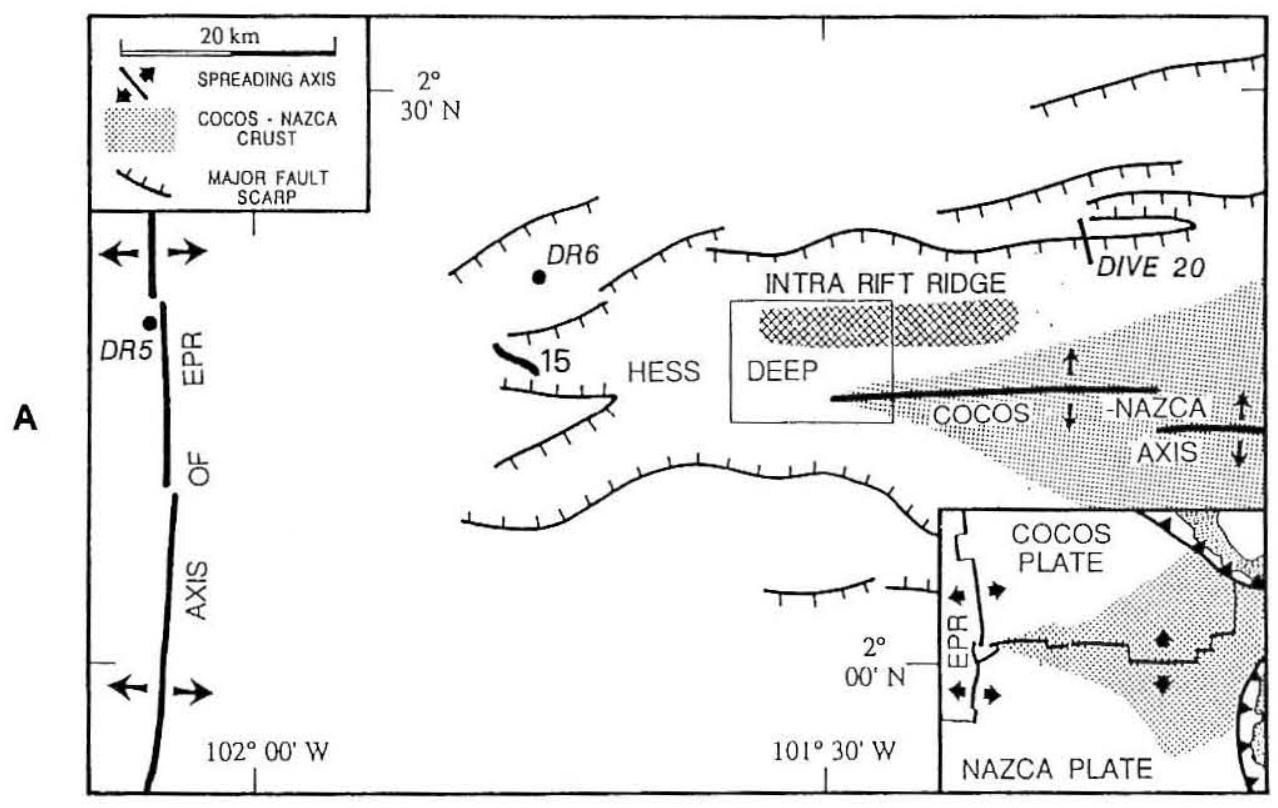

Fig. 1. (a) Generalized tectonic sketch map of the Cocos-Nazca spreading center and the East pacific Rise. Dive sites 20 on the northern wall of the Intrarift ridge and 15 located west of the Cocos-Nazca propagator are shown. Dredge hauls DR6 and DR5 are from Eissen [1982]. (b) Bathymetric map (Sea Beam) of the Hess Deep region located near the tip of the Cocos-Nazca propagator showing the Nautile dive tracks (numbers along the tracks). The Sea Beam data were provided by H. Puchelt (University of Karlshue, Germany). A dredge haul collected by the Scripps Institution of Oceanography containing metagabbros, basalt, and sheared serpentinized peridotite is shown (J. Natland, personal communication, 1991). The circles on dive tracks 3 and 4 are the location of corresponding basalts (3-10 and 4-14) used in Figure 5. The Hess Deep and the Intrarift ridge (IRR) are indicated. The lettering along the tracks indicates the locations of mylonites (M), cataclastic breccia (CT), and serpentinized breccia (SB) suggestive of tectonic motions. 


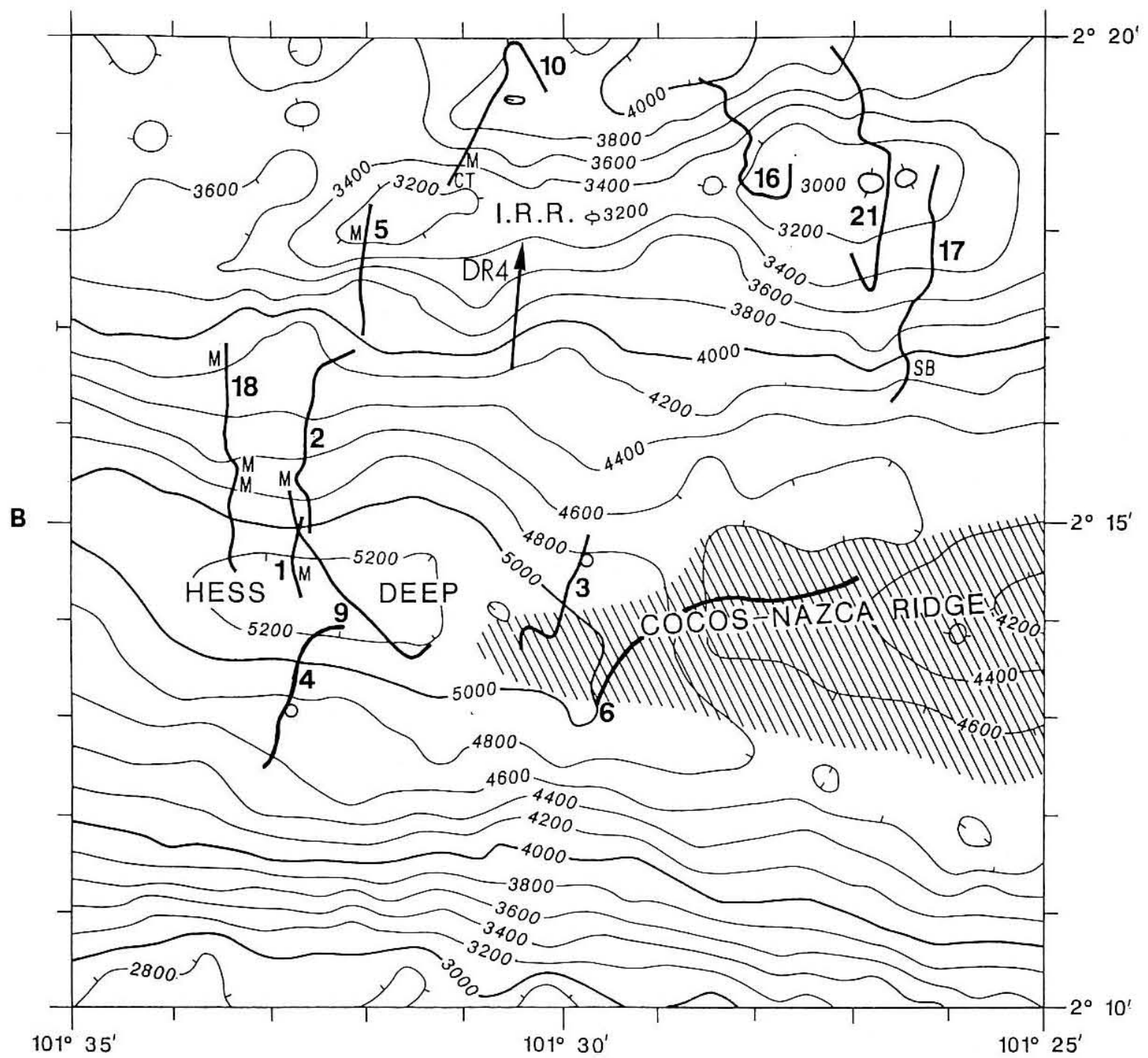

Fig. 1. (continued)

"holly leaf" spinels (Cr\# 0.56, Mg\# 0.37) are found only in the harzburgitic portion of the rock (Plates $1 b$ and $2 b$ ). The composition ( $\mathrm{wo}_{02}$-en $\mathrm{en}_{84}-\mathrm{fs}_{14}$ ) of the wehrlitic clinopyroxene in the wehrlitic zone of sample 17-9 is similar to that of the clinopyroxene exsolution lamellae in orthopyroxene, and also the olivine shows a lower forsterite content $\left(\mathrm{Fo}_{84}\right)$ than in the nonimpregnated part of the harzburgite. The minerals forming the wehrlitic constituents are undeformed (plagioclase and clinopyroxene) or show rare kink bands (olivine). The whole rock (17-9) is criss-crossed by secondary veins and veinlets of talc and chrysotile. Near the veins, the orthopyroxene is altered into tremolite.

Dunites. The dunites $(9-8,9-9,17-12$, and 17-14) are encountered near the southern foot of the Intrarift ridge and can be recognized by the homogeneous polygonal mesh texture of their olivine ghosts (up to $4 \mathrm{~mm}$ in diameter) made up of serpentine and rimmed with secondary magnetite (Figures $1 b$, 2, and 3 and Plate $1 h$ ). The dunites are generally more alterated than the harzburgites and contain abundant veins of chrysotile (< $1 \mathrm{~cm}$ thick) which are concentrated in some portions of the samples (i.e., 17-12). The serpentinized dunites exhibit a faint foliation and occasionally contain scarce (9-9) to abundant (9-7) amoeboid plagioclase. Rounded to idiomorphic chromite grains $(<2 \%$, about $0.1 \mathrm{~mm}$ in diameter) are generally well preserved, but olivine relics $\left(\mathrm{F}_{87-89}\right)$ are rare (17-14). Sample 9-7, in particular, shows modal variation grading from dunite to chromite-bearing dunite (up to $5 \%$ chromite) and from plagioclase-dunite to troctolite (up to $50 \%$ plagioclase locally). This rock exhibits alternating layers of lenticular gabbroic material and enriched dunitic zones (Plates $1 c$ and $1 g$ and Table 1). The gabbroic layers are made up of plagioclase, olivine, and clinopyroxene assemblages which ressemble a cumulate texture with undeformed amoeboid plagioclase as an intercumulus phase and with scarce interstitial "vermicular" clinopyroxene $\left(\mathrm{wo}_{45^{-}}\right.$ $\mathrm{en}_{50}-\mathrm{fs}_{05}$ ) rimming the contact between olivine and plagioclase (Plate $2 d$ and Table 2). These textural features suggest the impregnation of unconsolidated dunitic material by basaltic melts, as described by Cannat et al. [1990] in similar rocks types recovered from the Garrett fracture zone (EPR, near $13^{\circ} \mathrm{S}$ ). Plagioclase is locally altered into prelunite and/or hydrogarnet, and olivine is generally well preserved in the impregnated portions of the samples. Chlorite, yellowish clay minerals and Fe-hydroxides are also found as alteration products in the outer rims and along cracks of the brecciated serpentinized dunites 


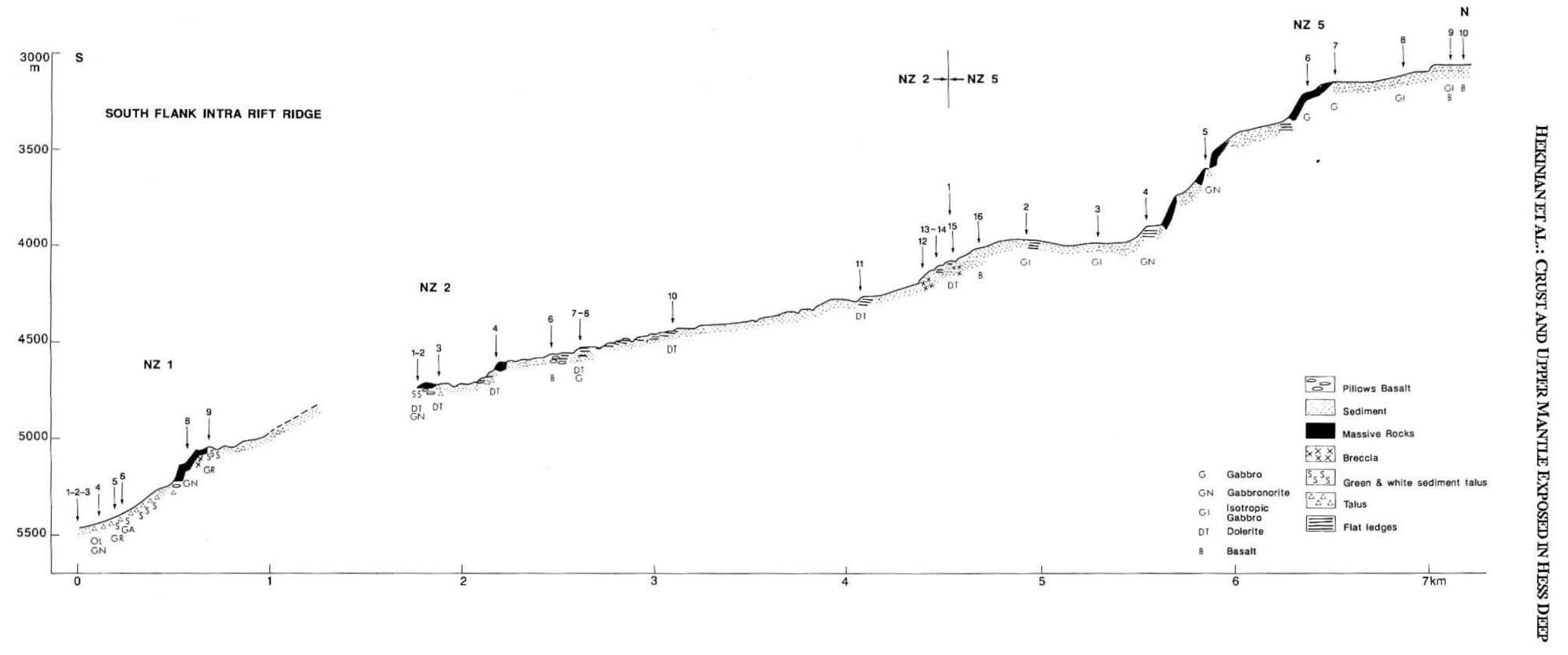

Fig. 2. Geological profile of Nazcopac (Nz) dives 1,2, and 5 conducted along the southern flank of the Intrarift ridge near the Hess Deep (Figure 1). The dive numbers and the samples $(1,2$, etc.) are shown. Vertical exageration is $1 \times 1$. The flat ledges outcrops may consist of doleritic sills. 

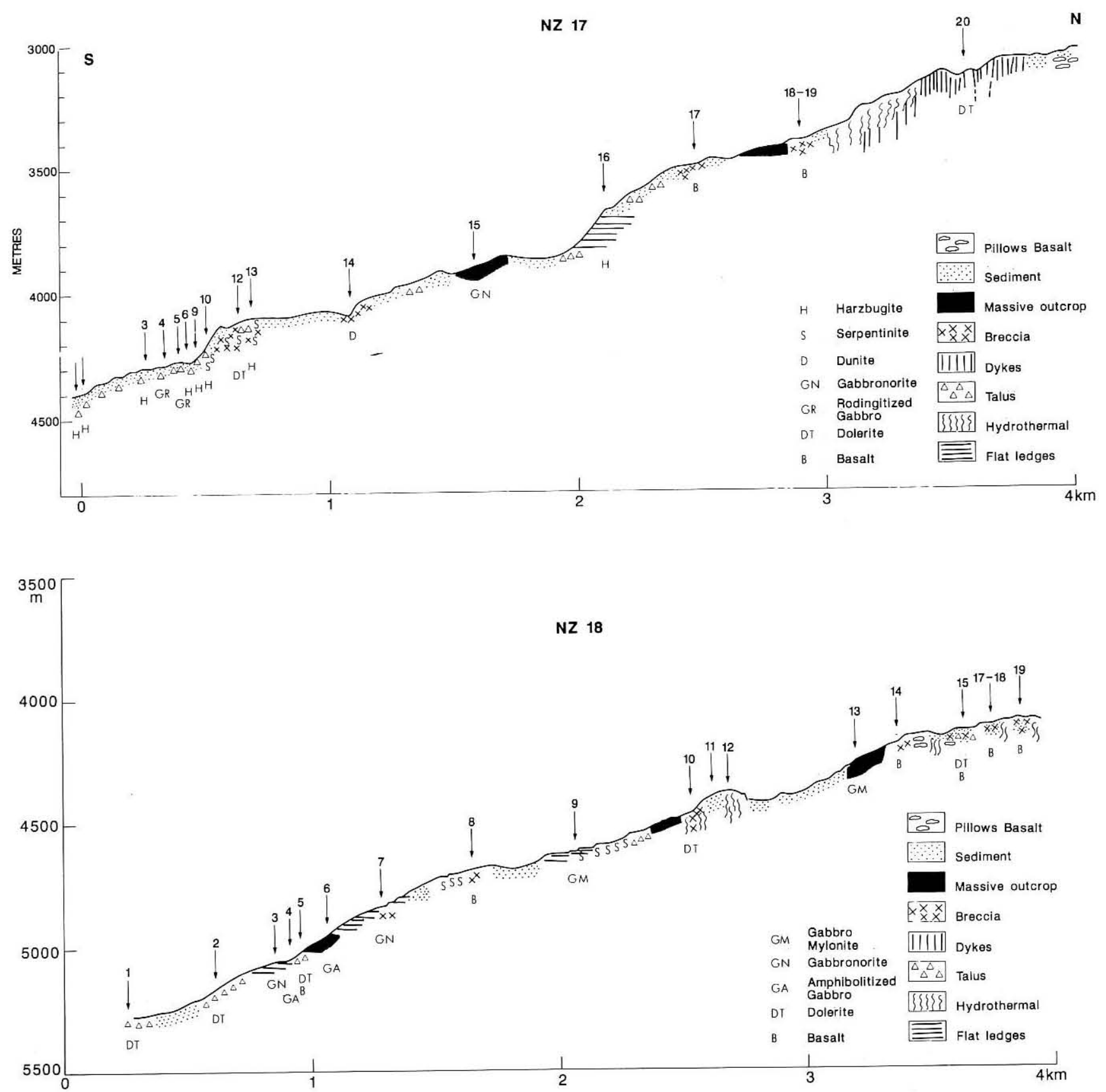

Fig. 3. Geological profiles of dives 17 and 18 along the eastern and western southern flank of the Intrarift ridge respectively. The symbols are the same as in Figure 2. The flat ledge outcrops consist of subparallel serpentinized peridotite (i.e., 17-16), foliated mylonite (18-9), and gabbro (18-3).

TABLE 1. Nazcopac Samples Recovered by the Submersible Nautile in the Hess Deep Near the Galapagos Triple Junction (Central Eastern Pacific)

\begin{tabular}{llll}
\hline Sample & Depth, $\mathrm{m}$ & \multicolumn{1}{c}{ Sample Description } & \multicolumn{1}{c}{ Geological Setting } \\
\hline $1-1$ & 5454 & brown pelagic sediment & mud (axial trough) \\
$1-2$ & 5454 & brown pelagic sediment & mud (axial trough) \\
$1-3$ & 5454 & sediment and rodingitized gabbroic cumulate & rubble (south wall of Intrarift ridge) \\
$1-4$ & 5442 & coarse grained olivine gabbronorite & rubble (south wall of Intrarift ridge) \\
$1-5$ & 5413 & rodingitized gabbroic mylonite & rubble and megablock (south wall of Intrarift ridge) \\
$1-6$ & 5374 & olivine gabbro to anorthosite & rubble (south wall of Intrarift ridge) \\
$1-8$ & 5145 & cumulate gabbronorite & foot of megablock (south wall of Intrarift ridge) \\
$1-9$ & 5057 & striated rodingitized gabbro & top of scarp (south wall of Intrarift ridge) \\
$2-1$ & 4737 & dolerite & fault scarp (south wall of Intrarift ridge) \\
$2-2$ & 4724 & cumulate gabbronorite and stiky sediment & megablock and detrital sediment (south wall of Intrarift ridge)
\end{tabular}


TABLE 1. (Continued)

\begin{tabular}{|c|c|c|c|}
\hline Sample & Depth, m & Sample Description & Geological Setting \\
\hline $2-3$ & 4717 & metadolerite breccia & step or bench, in situ sample (south wall of Intrarift ridge) \\
\hline $2-4$ & 4638 & prismatic dolerite & in situ outcrop (south wall of Intra-rift ridge) \\
\hline $2-6$ & 4572 & altered basalt & rubble on slope (south wall of Intrarift ridge) \\
\hline $2-7$ & 4527 & noncumulate metagabbro & in situ on scarp (south wall of Intrarift ridge) \\
\hline $2-8$ & 4519 & metadolerite & in situ on flat ledge (south wall of Intrarift ridge) \\
\hline $2-10$ & 4463 & metadolerite & rubble on flat ledge (south wall of Intrarift ridge) \\
\hline $2-11$ & 4263 & dolerite & flat ledge (south wall of Intrarift ridge) \\
\hline $2-12$ & 4152 & breccias and detrital sediment & sedimented area (south wall of Intrarift ridge) \\
\hline $2-13$ & 4128 & sediment & rubble on sedimented slope (south wall of Intrarift ridge) \\
\hline $2-14$ & 4103 & pelagic and detrital sediment & sedimented area (south wall of Intrarift ridge) \\
\hline $2-15$ & 4070 & brecciated material & in situ (south wall of Intrarift ridge) \\
\hline $2-16$ & 4059 & basalt & basalt outcrop (south wall of Intrarift ridge) \\
\hline $2-17$ & 4029 & detrital and pelagic sediment & talus (south wall of Intrarift ridge) \\
\hline $3-1$ & 5203 & buff indurated sediment & pelagic sediment (nose of Cocos-Nazca axial ridge) \\
\hline $3-2$ & 5200 & basalt & from large gja (nose of Cocos-Nazca axial ridge) \\
\hline $3-3$ & 5211 & basalt & from collapse pit (nose of Cocos-Nazca axial ridge) \\
\hline $3-4$ & 5210 & basalt & from collapse pit (nose of Cocos-Nazca axial ridge) \\
\hline $3-5$ & 5141 & basalt & in situ (nose of Cocos-Nazca axial ridge) \\
\hline $3-6$ & 5114 & basalt & in situ (nose of Cocos-Nazca axial ridge) \\
\hline $3-7$ & 5115 & basalt & in situ (nose of Cocos-Nazca axial ridge) \\
\hline $3-8$ & 5064 & dolerite & in situ(south wall of Intrarift ridge) \\
\hline $3-9$ & 5000 & basalt & outcrop (south wall of Intrarift ridge) \\
\hline $3-10$ & 4896 & basalt & outcrop (south wall of Intrarift ridge) \\
\hline $3-11$ & 4589 & metabasalt & outcrop on spur (south wall of Intrarift ridge) \\
\hline $5-1$ & 4080 & metadolerite & talus (south wall of Intrarift ridge) \\
\hline $5-2$ & 3954 & noncumulate gabbro & talus (south wall of Intrarift ridge) \\
\hline $5-3$ & 3982 & noncumulate olivine gabbro & talus (south wall of Intrarift ridge) \\
\hline $5-4$ & 3909 & cumulate metagabbronorite & flat ledges (south wall of Intrarift ridge) \\
\hline $5-5$ & 3596 & cumulate metagabbronorite & top of ledge (south wall of Intrarift ridge) \\
\hline $5-6$ & 3232 & metagabbro & in situ on scarp (south wall of Intrarift ridge) \\
\hline $5-7$ & 3163 & mylonitic gabbro & in situ on scarp (near top of Intrarift ridge) \\
\hline $5-8$ & 3091 & noncumulate metagabbro & rubble and sediment (near top of Intrarift ridge) \\
\hline $5-9$ & 3067 & noncumulate gabbronorite & in situ on dike (near top of Intrarift ridge) \\
\hline $5-10$ & 3103 & sediment & flat sedimented area (top of Intrarift ridge) \\
\hline $9-1$ & 5263 & basalt (pillow) & glassy basalt outcrop (eastem end of Hess Deep) \\
\hline $9-2$ & 5407 & basalt (pillow) & glassy basalt outcrop (eastern end of Hess Deep) \\
\hline $9-3$ & 5372 & amphibolitized metagabbro & on steep mud slope with blocks (south wall of Intrarift ridge) \\
\hline 9.4 & 5333 & altered breccias & long rocky spur (south wall of Intrarift ridge) \\
\hline $9-5$ & 5327 & noncumulate gabbro & mud slope with angular rocks (south wall of Intrarift ridge) \\
\hline $9-6$ & 5341 & mesocratic olivinegabbro & mud slope with scatered boulders (south wall of Intrarift ridge) \\
\hline $9-7$ & 5341 & troctolite to chromite dunite & same site as 9-6 (south wall of Intrarift ridge) \\
\hline $9-8$ & 5311 & serpentinized dunite & brecciated rocks in whitish matrix (south wall of Intrarift ridge) \\
\hline $9-9$ & 5311 & serpentinized Pl-dunite/detritle sediment & same site as 9-8 (south wall of Intrarift ridge) \\
\hline $9-10$ & 5305 & cumulate olivine gabbro to anorthosite & same site as 9-8 (south wall of Intrarift ridge) \\
\hline $9-11$ & 5305 & metabasalt (picritic basalt) & same site as 9-8 (south wall of Intrarift ridge) \\
\hline $9-12$ & 5261 & cumulate metagabbro & large irregular outcrops (south wall of Intrarift ridge) \\
\hline $9-13$ & 5135 & rodingitized gabbro & large boulders buried in mud (south wall of Intrarift ridge) \\
\hline $9-14$ & 5136 & foliated metagabbro & same site as $9-13$ (south wall of Intrarift ridge) \\
\hline $9-15$ & 5113 & dolerite & hackly rock surface (south wall of Intrarift ridge) \\
\hline $9-16$ & 5103 & cumulate olivine gabbro & outcrop over ledge of next sample (south wall of Intrarift ridge) \\
\hline $9-17$ & 5096 & olivine gabbro/basalt (carbonate veins) & ledge under previous sample (south wall of Intrarift ridge) \\
\hline $9-18$ & 4983 & rodingitized metagabbronorite & on steep slope with mud (south wall of Intrarift ridge) \\
\hline $9-19$ & 4780 & dolerite & loose rocks and massive outcrops (south wall of Intrarift ridge) \\
\hline $9-20$ & 4780 & mylonitized olivine microgabbro & striated rock (south wall of Intrarift ridge) \\
\hline $10-1$ & 4032 & metabasalt & talus slope (north wall of Intrarift ridge) \\
\hline $10-2$ & 3966 & dolerite & (small volcanic ridge north of Intrarift ridge) \\
\hline $10-3$ & 3918 & prismatic metadolerite & (small volcanic ridge north of Intrarift ridge) \\
\hline $10-4$ & 3909 & basalt impregnation in dolerite & talus (small volcanic ridge north of Intrarift ridge) \\
\hline $10-5$ & 3785 & basalt and FeMn crust & in situ on scarp (small volcanic ridge north of Intrarift ridge) \\
\hline $10-6$ & 3652 & basalt (pillow) & in situ on scarp (small volcanic ridge north of Intrarift ridge) \\
\hline $10-7$ & 3716 & dolerite & talus (north wall of Intrarift ridge) \\
\hline $10-8$ & 3630 & basalt & talus (north wall of Intrarift ridge) \\
\hline $10-9$ & 3468 & gabbronorite & in situ (north wall of Intrarift ridge) \\
\hline $10-11$ & 3441 & mylonitic gabbro & in situ (north wall of Intrarift ridge) \\
\hline
\end{tabular}


TABLE 1. (Continued)

\begin{tabular}{|c|c|c|c|}
\hline Sample & Depth, m & Sample Description & Geological Setting \\
\hline $10-12$ & 3371 & indurated sediment & in situ (north wall of Intrarift ridge) \\
\hline $10-13$ & 3357 & cataclastic metagabbro/metadolerite & talus (north wall of Intrarift ridge) \\
\hline $10-14$ & 3286 & nonfoliated amphibolite (metagabbro) & talus (north wall of Intrarift ridge) \\
\hline $10-15$ & 3211 & noncumulate gabbro & in situ (north wall of Intrarift ridge) \\
\hline $10-16$ & 3177 & noncumulate metagabbro & outcrop (north wall of Intrarift ridge) \\
\hline $10-17$ & 3167 & noncumulate gabbro & in situ layered outcrop (north wall of Intrarift ridge) \\
\hline $10-18$ & 3074 & basalt & rubble (top of Intrarift ridge) \\
\hline $16-1$ & 3963 & indurated sediment & (north wall of Intrarift ridge) \\
\hline $16-2$ & 3963 & basalt (pillow) & rubble (north wall of Intrarift ridge) \\
\hline $16-3$ & 3975 & basalt (pillow) & rubble and sediment (north wall of Intrarift ridge) \\
\hline $16-4$ & 3854 & prismatic dolerite & rubble and sediment (north wall of Intrarift ridge) \\
\hline $16-5$ & 3645 & basalt (pillow) & rubble (north wall of Intrarift ridge) \\
\hline $16-6$ & 3540 & dolerite & rubble (north wall of Intrarift ridge) \\
\hline $16-7$ & 3407 & dolerite & rubble and sediment (north wall of Intrarift ridge) \\
\hline $16-8$ & 3366 & dolerite & rubble (north wall of Intrarift ridge) \\
\hline $16-9$ & 3250 & dolerite & rubble and sediment (north wall of Intrarift ridge) \\
\hline $16-10$ & 3188 & dolerite & in situ on dike and rubble (north wall of Intrarift ridge) \\
\hline $16-11$ & 3093 & hydrothermal sediment & hydrothermal deposit (top of Intrarift ridge) \\
\hline $16-12$ & 3098 & altered basalt & outcrop (top of Intrarift ridge) \\
\hline $16-13$ & 3082 & hydrothermal sediment & hydrothermal deposit (top of Intrarift ridge) \\
\hline $16-14$ & 3082 & hydrothermal sediment & hydrothermal deposit (top of Intrarift ridge) \\
\hline $16-15$ & 3079 & hydrothermal sediment & hydrothermal deposit (top of Intrarift ridge) \\
\hline $16-16$ & 2993 & basalt (pillow) & rubble (top of Intrarift ridge) \\
\hline $16-17$ & 2971 & hydrothermal breccia & hydrothermal deposit (top of Intrarift ridge) \\
\hline $16-18$ & 2967 & hydrothermal breccia and pillow fragments & hydrothermal deposit (top of Intrarift ridge) \\
\hline $16-19$ & 3027 & indurated sediment & sedimented step or bench (top of Intrarift ridge) \\
\hline $16-20$ & 3013 & basalt & rubble (top of Intrarift ridge) \\
\hline $16-21$ & 3013 & basalt & rubble (top of Intrarift ridge) \\
\hline $17-1$ & 4453 & serpentinized harzburgite & blocks (south wall of Intrarift ridge) \\
\hline $17-2$ & 4401 & serpentinized harzburgite & rubble (south wall of Intrarift ridge) \\
\hline $17-3$ & 4299 & serpentinized harzburgite & massive blocks (south wall of Intrarift ridge) \\
\hline $17-4$ & 4290 & partially rodingitized gabbro & blocks on slope (south wall of Intrarift ridge) \\
\hline $17-5$ & 4268 & serpentinite harzburgite & blocks on slope (south wall of Intrarift ridge) \\
\hline $17-6$ & 4268 & partially rodingitized olivine gabbro & blocks on slope (south wall of Intrarift ridge) \\
\hline $17-7$ & 4234 & deformed cumulate gabbro & striated horizontal blocks (south wall of Intrarift ridge) \\
\hline $17-8$ & 4239 & harzburgite and lherzolite & striated horizontal blocks (south wall of Intrarift ridge) \\
\hline $17-9$ & 4239 & harzburgite and PI-Wherlite/chrysotile vein & striated horizontal blocks (south wall of Intrarift ridge) \\
\hline $17-10$ & 4191 & serpentinized harzburgite (carbonate veins) & in situ on step (south wall of Intrarift ridge) \\
\hline $17-11$ & 4171 & brecciated dolerite & rubble (south wall of Intrarift ridge) \\
\hline $17-12$ & 4105 & brecciated serpentinized dunite and talc & faulted outcrop (south wall of Intrarift ridge) \\
\hline $17-13$ & 4100 & serpentinized harzburgite & in situ oriented sample (south wall of Intrarift ridge) \\
\hline $17-14$ & 4046 & serpentinized dunite & breccia, foliated (south wall of Intrarift ridge) \\
\hline $17-15$ & 3885 & foliated cumulate gabbronorite & large outcrop (south wall of Intrarift ridge) \\
\hline $17-16$ & 3632 & serpentinized harzburgite & in situ sub-vertical ledge (south wall of Intrarift ridge) \\
\hline $17-17$ & 3466 & basalt & brecciated material on apron (south wall of Intrarift ridge) \\
\hline $17-18$ & 3357 & hyaloclastite & brecciated (south wall of Intrarift ridge) \\
\hline $17-19$ & 3357 & altered basalt & brecciated (south wall of Intrarift ridge) \\
\hline $17-20$ & 3103 & dolerite & dikes outcrop (south wall of Intrarift ridge) \\
\hline $18-1$ & 5264 & prismatic dolerite & rubble (south wall of Intrarift ridge) \\
\hline $18-2$ & 5159 & prismatic dolerite & rubble on slope (south wall of Intrarift ridge) \\
\hline $18-3$ & 5057 & foliated cumulate olivine gabbronorite & in situ slickenside blocks (south wall of Intrarift ridge) \\
\hline $18-4$ & 5033 & amphibolitized metagabbro & rubble (south wall of Intrarift ridge) \\
\hline $18-5$ & 5012 & prismatic dolerite and olivine-basalt & rubble (south wall of Intrarift ridge) \\
\hline $18-6$ & 4963 & amphibolitized metagabbro & in situ oriented sample (south wall of Intrarift ridge) \\
\hline $18-7$ & 4843 & purple mylonitic breccia & in situ (south wall of Intrarift ridge) \\
\hline $18-8$ & 4680 & hyaloclastite & layered outcrop (south wall of Intrarift ridge) \\
\hline $18-9$ & 4569 & gabbroic mylonite & in situ foliated outcrop (south wall of Intrarift ridge) \\
\hline $18-10$ & 4477 & brecciated metadolerite & FeMn mound (south wall of Intrarift ridge) \\
\hline $18-11$ & 4397 & semiconsolidated detrital sediment & mound top (south wall of Intrarift ridge) \\
\hline $18-12$ & 4388 & hydrothermal sediment & hydrothermal mound (south wall of Intrarift ridge) \\
\hline $18-13$ & 4267 & mylonitized metagabbro & rubble and sediment (south wall of Intrarift ridge) \\
\hline $18-14$ & 4177 & basalt breccia and FeMn crust & rock mixture on slope (south wall of Intrarift ridge) \\
\hline $18-15$ & 4143 & prismatic dolerite and basalt breccia & talus (south wall of Intrarift ridge) \\
\hline $18-17$ & 4153 & basalt breccia and FeMn crust & in situ outcrop (south wall of Intrarift ridge) \\
\hline $18-19$ & 4123 & basalt & in situ brecciated material (south wall of Intrarift ridge) \\
\hline
\end{tabular}


TABLE 1. (Continued)

\begin{tabular}{llll}
\hline Sample & Depth, $\mathrm{m}$ & \multicolumn{1}{c}{ Sample Description } & \multicolumn{1}{c}{ Geological Setting } \\
\hline $18-20$ & 4108 & breccia of altered basalt and FeMn crust & (south wall of Intrarift ridge) \\
$20-1$ & 4209 & vesicular massive basalt & \\
$20-2$ & 4085 & dolerite & rounded boulder on talus (north wall of Hess Deep) \\
$20-3$ & 3714 & dolerite & $\begin{array}{l}\text { prismatic rock on talus (north wall of Hess Deep) } \\
\text { prismatic rock on talus (north wall of Hess Deep) }\end{array}$ \\
$20-4$ & 3146 & fine grained dolerite & steep ramp at talus top (north wall of Hess Deep) \\
$20-5$ & 3046 & noncumulate olivine gabbronorite & in situ massive rock (north wall of Hess Deep) \\
$20-6$ & 2927 & noncumulate olivine gabbronorite & from dikes (north wall of Hess Deep) \\
$20-7$ & 2473 & breccia and FeMn Crust & (north wall of Hess Deep) \\
$20-8$ & 2366 & basalt & near outcrop of dikes (north wall of Hess Deep) \\
$20-9$ & 1820 & basalt (pillow) & in situ (north wall of Hess Deep) \\
$20-10$ & 1846 & prismatic dolerite & massive flow (north wall of Hess Deep) \\
$20-11$ & 1733 & vesicular massive basalt/Fe-Oxihydroxides & loose block on top of flow (north wall of Hess Deep) \\
$20-12$ & 1700 & gabbro and dolerite & loose blocks on top of flow (north wall of Hess Deep) \\
$20-13$ & 1677 & dolerite & top of flow (north wall of Hess Deep) \\
& & & \\
$21-1$ & 3773 & dolerite & talus (north wall of Intrarift ridge) \\
$21-2$ & 3773 & dolerite & talus (north wall of Intrarift ridge) \\
$21-3$ & 3646 & dolerite & talus (north wall of Intrarift ridge) \\
$21-4$ & 3539 & dolerite & dike outcrop (north wall of Intrarift ridge) \\
$21-5$ & 3500 & dolerite & near dike outcrop (north wall of Intrarift ridge) \\
$21-6$ & 3411 & dolerite & dike outcrop (north wall of Intrarift ridge) \\
$21-7$ & 3374 & dolerite & dike outcrop (north wall of Intrarift ridge) \\
$21-8$ & 3301 & FeMn crust & dike outcrop (north wall of Intrarift ridge) \\
$21-9$ & 3166 & altered dolerite & dike outcrop (north wall of Intrarift ridge) \\
$21-10$ & 3078 & indurated sediment & dike outcrop (north wall of Intrarift ridge) \\
$21-11$ & 3078 & basalt (pillow) & dike outcrop (north wall of Intrarift ridge) \\
$21-12$ & 3020 & basaltic breccia and FeMn Crust & (top of Intrarift ridge) \\
\hline & & &
\end{tabular}

TABLE 2. Bulk Rock Analyses of Intrusives and Extrusives Recovered by Submersible From the Intrarift Ridge in the Hess Deep

\begin{tabular}{|c|c|c|c|c|c|c|c|c|c|c|}
\hline & $\begin{array}{c}\text { Nz17-1 } \\
\text { Harzburgite }\end{array}$ & $\begin{array}{c}\text { Nz9-7 } \\
\text { Chr-Dunite }\end{array}$ & $\begin{array}{l}\text { Nz9-7* } \\
\text { Troctolite }\end{array}$ & $\begin{array}{c}\text { Nz9-6 } \\
\text { Olv.Gabbro }\end{array}$ & $\begin{array}{c}\text { Nz10-9 } \\
\text { Gabbronor }\end{array}$ & $\begin{array}{c}\text { Nz5-2 } \\
\text { Isotr.Gabbr }\end{array}$ & $\begin{array}{l}\text { Nz10-7 } \\
\text { Dolerite }\end{array}$ & $\begin{array}{l}\text { Nz16-4 } \\
\text { Dolerite }\end{array}$ & $\begin{array}{c}\text { Nz16-2 } \\
\text { Basalt }\end{array}$ & $\begin{array}{c}\text { Nz10-5 } \\
\text { Basalt }\end{array}$ \\
\hline \multicolumn{11}{|c|}{ Oxides, in Weight Percent } \\
\hline $\mathrm{SiO}_{2}$ & 39.63 & 36.92 & 37.78 & 44.25 & 50.85 & 51.01 & 49.23 & 48.96 & 49.07 & 49.69 \\
\hline $\mathrm{TiO}_{2}^{2}$ & 0.02 & 0.03 & 0.05 & 0.11 & 0.56 & 0.65 & 1.09 & 0.94 & 1.00 & 1.00 \\
\hline $\mathrm{Al}_{2} \mathrm{O}_{3}$ & 0.76 & 3.65 & 10.25 & 20.17 & 16.46 & 15.74 & 17.54 & 16.74 & 16.60 & 16.27 \\
\hline $\mathrm{Fe}_{2}^{2} \mathrm{O}_{3}$ & 1.81 & 6.90 & 1.57 & 1.12 & 1.76 & 2.04 & 1.02 & 2.14 & 2.59 & 2.79 \\
\hline $\mathrm{FeO}^{3}$ & 5.77 & 2.98 & 5.94 & 3.09 & 4.84 & 5.31 & 6.91 & 6.06 & 6.37 & 5.64 \\
\hline $\mathrm{MnO}$ & 0.12 & 0.10 & 0.12 & 0.07 & 0.14 & 0.15 & 0.15 & 0.14 & 0.16 & 0.14 \\
\hline $\mathrm{MgO}$ & 38.07 & 34.25 & 28.50 & 14.58 & 8.69 & 8.77 & 8.24 & 9.50 & 9.26 & 9.27 \\
\hline $\mathrm{CaO}$ & 2.92 & 0.64 & 4.91 & 12.91 & 13.83 & 12.57 & 12.43 & 12.28 & 11.91 & 12.41 \\
\hline $\mathrm{Na}_{2} \mathrm{O}$ & 0.06 & 0.15 & 0.19 & 0.86 & 2.22 & 2.44 & 2.37 & 2.26 & 2.44 & 2.23 \\
\hline $\mathrm{K}_{2} \mathrm{O}$ & 0.01 & $\mathrm{tr}$ & 0.06 & 0.10 & 0.04 & 0.05 & 0.03 & 0.03 & 0.05 & 0.05 \\
\hline $\mathrm{P}_{2} \mathrm{O}_{5}$ & 0.01 & 0.13 & 0.01 & 0.01 & 0.03 & 0.04 & 0.07 & 0.06 & 0.06 & 0.07 \\
\hline I.L. & 9.70 & 12.18 & 9.20 & 3.02 & 1.25 & 1.27 & 0.44 & 0.68 & 0.58 & 0.68 \\
\hline Total & 98.78 & 97.93 & 98.69 & 100.26 & 100.70 & 100.04 & 100.32 & 99.99 & 100.09 & 100.24 \\
\hline \multicolumn{11}{|c|}{ Traces, in Part per Million } \\
\hline $\mathrm{Ba}$ & n.d. & $<5$ & n.d & 23 & 47 & 30 & 31 & 30 & n.d & n.d \\
\hline $\mathrm{Rb}$ & $<2$ & $<5$ & $<2$ & 2 & $<1$ & 1 & $<1$ & 83 & $<2$ & $<2$ \\
\hline $\mathrm{Sr}$ & 302 & $<5$ & 35 & 91 & 106 & 111 & 105 & 24 & 88 & 85 \\
\hline $\mathrm{Nb}$ & $<2$ & $<5$ & 3 & 2 & 2 & $<2$ & 3 & $<2$ & $<2$ & $<2$ \\
\hline $\mathrm{Zr}$ & 4 & 5 & 3 & 6 & 31 & 33 & 65 & 49 & 53 & 51 \\
\hline $\mathrm{Y}$ & 3 & $<5$ & 4 & 5 & 16 & 18 & 27 & 24 & 25 & 25 \\
\hline $\mathrm{Cr}$ & 2467 & 6583 & 3322 & 687 & 313 & 148 & 263 & 415 & 357 & 392 \\
\hline $\mathrm{Ni}$ & 2294 & 1310 & 1281 & 416 & 117 & 101 & 130 & 194 & 174 & 163 \\
\hline
\end{tabular}

Analyses were performed at the University of Karslruhe by using a Philips XRF authomated spectometers. Sample 9-7 is a dunite

(olivine+chromite) partly impregnated with gabbroic liguids (olivine+plagioclase+minor clinopyroxene) in the troctolitic portion.

(17-12, Table 1). Sample $9-9$ is a breccia composed of plagioclase-dunite fragments associated with sandy sediment containing mafic detrital minerals (Table 1).

\section{Gabbroic Recks}

The gabbroic rocks were among the most abundant samples encountered on the Intrarift ridge system [Francheteau et al., 1990] during dives $1,2,5,9,10,17$, and 18 (Figures 1, 2, and
3). They are divided according to their grain size, textures, and mineral association into olivine gabbro cumulates, gabbronorite cumulates, noncumulate (isotropic) gabbros, and metagabbros. Among the metagabbros, a particularly interesting group of samples are the amphibolitized gabbros (1-9, 10-14, and 18-5) which contain more than $25 \%$ poikilitic actinolite.

Olivine gabbro cumulates. As was seen for the ultramafic rocks, the cumulate olivine gabbros $(1,9,17$, and 18) occur near 

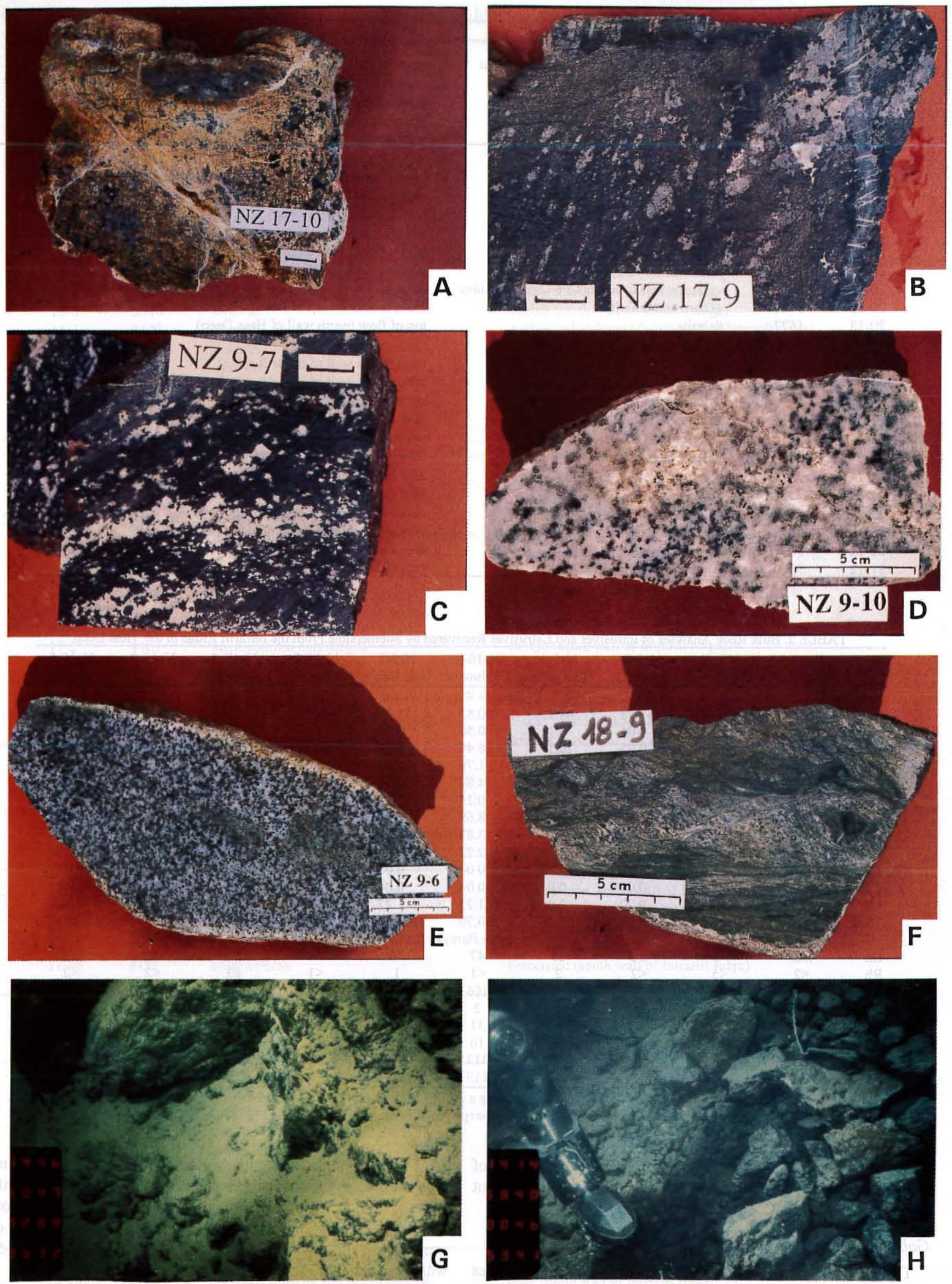
the foot of the southern flank of the Intrarift ridge (Figures 1, 2, and 3$)$. The samples are generally medium $(0.2-2 \mathrm{~mm}$ in diameter) to coarse-grained $(0.5-4 \mathrm{~mm}$ in diameter), leucocratic to mesocratic gabbros (Table 1 and Plates $1 d$ and $1 e$ ). Most of the olivine gabbros show heteradcumulate textures of plagioclase and olivine, with pyroxene as an intercumulus phase. In the samples 1-4 and 9-16, orthopyroxene exhibits clinopyroxene exsolution lamellae. Some specimens of olivine gabbros exhibit a wide range of modal compositions from locally pure anorthosite to olivine gabbro and troctolite (1-6 and 9-10) within a single sample. In this type of sample, interstitial "vermicular" clinopyroxene (9-6 and 1-6) found at contact between olivine and plagioclase has a similar chemical composition to that of the impregnated ultramafics. The most mafic rocks (1-4, 9-6, 9-16, and 17-6) contain scarce $(<1 \%)$ chromite and show a broad foliation (9-10 and 18-3) due to the orientation of elongated clinopyroxene (18-3). Plastically deformed features are uncommon and limited to scarce pyroxenes showing kink-bands or crushed crystals (18-3). One sample (9-20) is believed to be an ancient cumulate of olivine gabbro whose original texture was annealed after intense shear deformation under high temperature conditions.

The olivine gabbro cumulates are partially and completely rodingitized (1-6 and 17-6), leading to partial or complete transformation of plagioclase into hydrous calc-silicates (prehnite, zeolites, epidote) as a result of metasomatism by $\mathrm{Ca}^{++}$-enriched solutions expelled during the serpentinization of the associated ultramafic rocks [e.g., Honnorez and Kirst, 1975, Bideau et al., 1991]. The presence of numerous aragonite veins (sample 9-17) is also suggestive of calcium mobility. In most samples, plagioclase is partially altered into prehnite or zeolite, pyroxene is often uralitized, and olivine is variably transformed into talc-magnetite assemblages, serpentine, or yellow-brown smectites. The occurrence of albitized plagioclase in a portion of sample $9-16$ is probably related to a separate metamorphic event prior to rodingitization.

Gabbronorite cumulates. Gabbronorites (lacking olivine and chromite) are among the most common cumulates (Figures 2 and 3 , and Table 1) encountered along the south facing flank of the Intra-rift ridge area [Francheteau et al., 1990]. They generally differ from the olivine gabbro cumulates by their smaller grainsize (< $3 \mathrm{~mm}$ in diameter), and by their dark (mesocratic to melanocratic) coloration. The primary cumulate texture is often locally obliterated by a broad foliation and brecciation (1-8 and 10-11), but some portions of the rocks exhibit preserved plagioclase adcumulates associated with kinked clinopyroxene and orthopyroxene (1-8 and 9-14) in intercumulus position. Brown interstitial Ti-hornblende $\left(\mathrm{TiO}_{2}=3-4\right.$ wt \%) found in sample 5-4 probably has a magmatic origin. Large crystals of ilmenite and magnetite occur throughout. Pyroxene is rimmed by uralite (1-8 and 17-7) and large patches of green poikilitic actinolite $(5-6,9-14,18-4$, and 18-6) have locally recrystallized into mosaic aggregates (18-4 and 18-6). The plagioclase is variably albitized and the orthopyroxene is generally altered into chlorite-actinolite (10-9) and yellow clay minerals (5-4 and 1715). Monomineralic veins of chlorite, actinolite, zeolite, albite, quartz, prehnite, rare epidote (9-14) and carbonate (argonite) occur.

Noncumulate (isotropic) gabbros. The isotropic gabbros are melanocratic, medium to fine grained, and usually coarsergrained (0.1-2.0 $\mathrm{mm}$ in diameter) than the dolerites (Table 1). They are essentially made up of clinopyroxene and elongated (0.1-3 $\mathrm{mm}$ in length) laths of andesine and labradorite. The opaques, composed essentially of Ti-magnetite, do not exceed $5 \%$ of the bulk rock and olivine is found as trace constituents (< $2 \%$ ) in some samples $(5-3,10-16,20-6$, and 20-5). Usually, the isotropic gabbros have only trace amounts $(<0.1 \%)$ of orthopyroxene (10-16 and 20-12), but samples 20-6 and 20-5 exhibit large (up to $2.0 \mathrm{~mm}$ in diameter) poikilitic crystals (3$5 \%$ ) with abundant inclusions of plagioclase and clinopyroxene (Plate 2g). Similar coarse-grained poikilitic orthopyroxene xenocrysts found in tholeiitic lavas (sample CLDR4-2) from the axis of the EPR at $12^{\circ} 43 \mathrm{~N}$, were interpreted as having been formed in the upper part of the underlying magmatic reservoir [Hekinian et al., 1985]. The isotropic gabbros from the Hess Deep are compositionally comparable to the high-level gabbros described by Pallister and Hopson [1981] in the upper part of the gabbroic series in contact with the sheeted dike complex of the Samail ophiolite in Oman. Most of the isotropic gabbros are partially uralitized and contain albitized plagioclase. Brown amphiboles are included in the clinopyroxene of sample 10-16 and grade into green actinolite within the cleavage planes of the crystals as a possible transformation of a primary magmatic hornblende. Olivine is rarely preserved and is altered into talcmagnetite or clay minerals (5-3, 20-5 and 20-6). Orthopyroxene in sample 5-9 is altered into talc and/or chlorite and actinolite. Monomineralic veins of zeolites (9-5 and 10-16) and quartz (9-5) occasionally criss-cross the rocks.

Metagabbros and gabbroic mylonites. Many gabbroic samples, intensely modified by hydrothermal alteration or by cataclasis, have lost most of their primary igneous characteristics. Some specimens were tentatively identified as cumulate gabbronorites $(5-6,9-14,18-4$, and 18-6) or isotropic gabbros $(5-8)$ and were affected by alteration due to the circulation of seawater-derived solutions in the oceanic crust which enhanced amphibolitization and albitization. Based on textural evidences, sample 18-13 was probably a gabbronorite cumulate, and sample 9-3 was an isotropic gabbro. However, they contain abundant albitized plagioclase, rare uralitized clinopyroxene relics, strings of iron oxides (18-13), and large poikilitic crystals of green and brown amphiboles (9-3 and 1813) which are often recrystallized in mosaic aggregates (18-13, 18-4, and 18-6). Other pervasively amplibolitized samples (1-9 and $18-5$ ) have textural similarities to samples $18-4,18-6$, and

Plate 1. Photograph of impregnated and nonimpregnated harzburgites and gabbros from the Intrarift ridge of the Hess Deep in the Eastem Pacific Ocean (Figures 1 and 3). The bar indicates $1 \mathrm{~cm}$. (a) Serpentinized harzburgite (17-10) showing a fresh area of orthopyroxene lenses. The white veins consist of carbonate (aragonite), and the central part of the rock is abundantly altered into serpentinite, aragonite and smectite. (b) Foliated harzburgite ( 17-9) impregnated by plagioclase-welurlite. (c) Dunite (9-7) impregnated by gabbroic liquid (plagioclase and clinopyroxene). (d) Leucocratic olivine gabbro cumulate (9-10) with plagioclase, olivine and pyroxene (dark). (e) Mesocratic olivine-gabbro (9-6) containing abundant pyroxene and olivine. $(f)$ Gabbroic mylonite (189) showing foliated texture. $(g)$ Bottom photograph of a serpentinized mantle harzburgite collected from the southern flank of the Intrarift ridge (dive 17). A harzburgite sample $17-16$ was taken at a $5341 \mathrm{~m}$ depth. A thin veneer of pelagic sediment is observed on the slope. $(h)$ Bottom photograph taken at the foot of the Intrarift ridge near the intersection with the Hess Deep showing angular fragments of light green rocks. A sample of chromite-bearing dunite (sample 9-7) was collected at a depth of $3632 \mathrm{~m}$. 

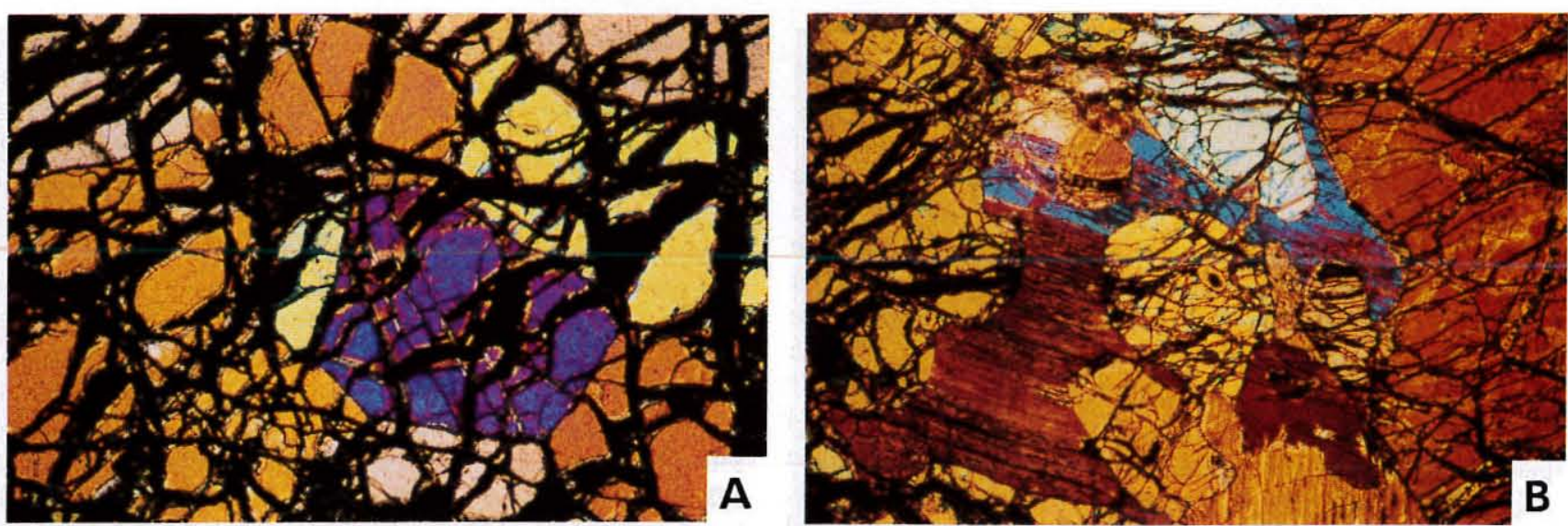

\section{$.70 \mathrm{~mm}$}
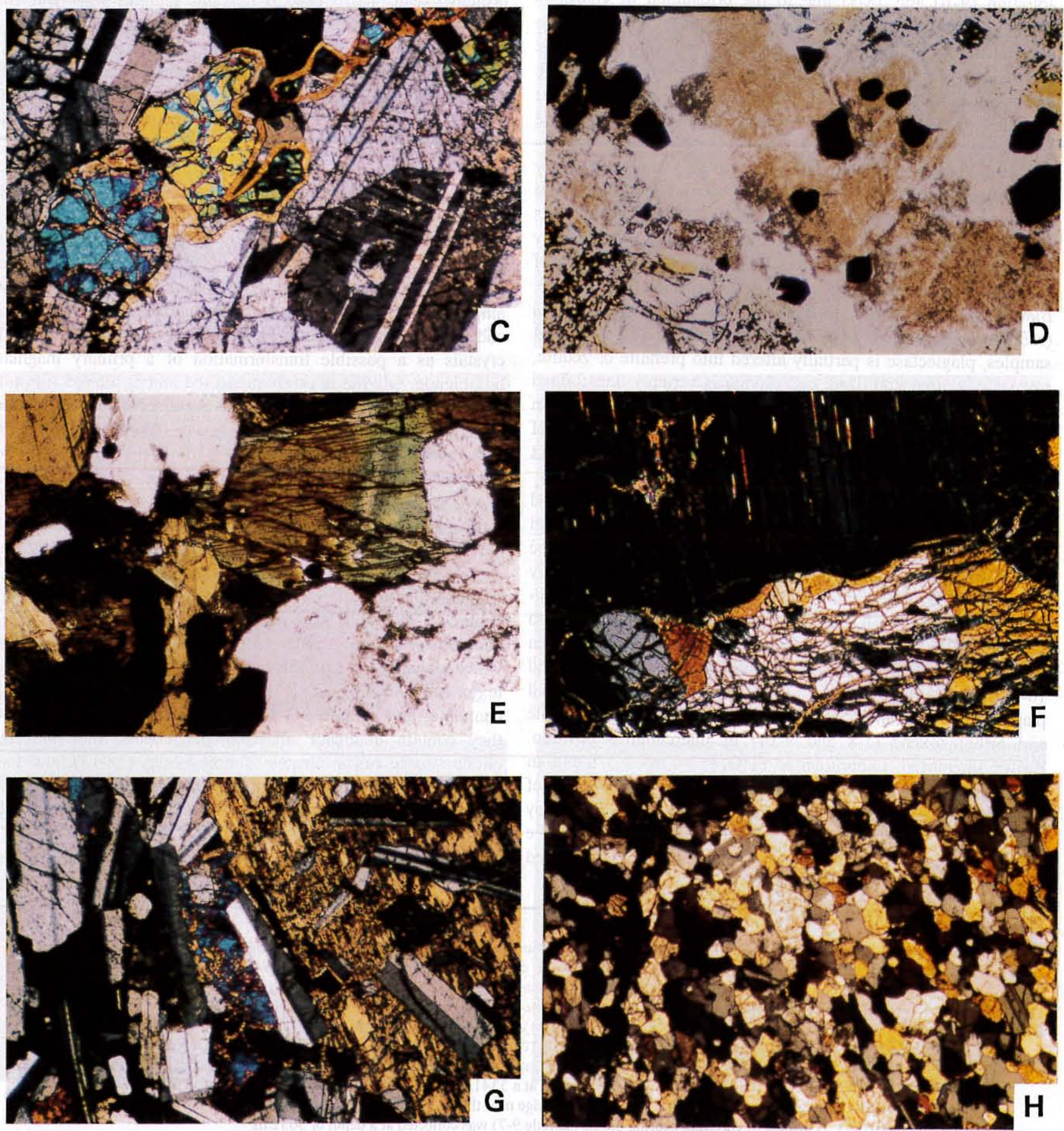
18-13 which are classified as metamorphosed gabbronorite cumulates. Most of these samples exhibit occasional veins of zeolite, quartz, or carbonate (aragonite). One case of extensive amphibolitization is represented by sample 10-14, composed of Ca-plagioclase $\left(\mathrm{an}_{43}\right)$, Na-plagioclase $\left(\mathrm{an}_{4-13}\right)$, ilmenitemagnetite integrowths, interstitial apatite, and pale brown hormblende grading progressively into green actinolite (Plate $2 e$ ). No foliation nor particular orientation was observed, and we believe that the rock was an amphibolitized gabbro whose textural and mineralogical characteristics were obliterated. A complete metamorphic transformation is also seen in the rodingites $(1-3,1-5,1-7,9-13,9-18$, and 17-4). These rocks have a milky coloration and contain the same type of calcsilicates (prehnite, zeolite, and epidote) as were seen in some portions of olivine gabbro cumulates (1-6 and 17-6). However, because of the lack of obvious olivine ghosts, the nature of the rodingite protoliths cannot be ascertained. These samples are intensely brecciated, and their plagioclase is usually completely altered into prehnite. In addition, clinopyroxene (1-5, 9-13, and 9-18) and orthopyroxene (17-4) relics are uncommon. Pyroxene is altered into actinolite fibers and chlorite-actinolite assemblages, and "hairlike"-shaped zeolite veins have invaded some large, albitized plagioclase crystals. Monomineralic veins of prehnite, zeolite, epidote, chlorite, actinolite, and clay minerals are common in the rodingites. Another case of transformation is shown by gabbroic mylonites. Some specimens were partly (5-5 and 18-6) to completely (5-7 and 18-9) crushed and sheared during cataclastic deformation (Plate $2 h$ ). The primary mineralogy is often recognizable in the porphyroclasts of the mortar textures, but the clasts are often recrystallized into albite, chlorite, and actinolite. Elongated aggregates of zeolite or epidote occur throughout in the shear planes or form criss-cross veinlets. One sample of olivine gabbro (9-20) is annealed and recrytallized in tiny mosaic crystals of homogeneous grain size (plagioclase, clinopyroxene, and ilmenite-magnetite) often surrounding larger olivine ghosts made up of talc and magnetite and locally filled with brown to yellow smectite (Plate $2 h$ ).

\section{Dolerites}

The dolerites have typical prismatic structures with angular edges for the freshest specimens and dulled to rounded edges for the altered rocks having thick $(0.5-1.5 \mathrm{~cm})$ dark rims. Most samples form talus piles (Table 1 and Figures 2 and 3), some of which were located at the foot of dike outcrops (17-20, 21-7, 218, and 21-9), often intermixed with gabbros (e.i., 2-1, 2- 8, and 20-2) and basalt (18-18). Other dolerites (2-8, 2-10, and 2-11) form partially dislocated, pavement like outcrops (Figure 2) of flat ledges ( $<20-50 \mathrm{~cm}$ thick). A few samples of dolerites were collected in place on dike outcrops, mainly during dive 21 (Table 1). Also, small fragments ( $<2 \mathrm{~cm}$ in diameter) forming breccias of altered dolerites $(2-10,18-17$, and 17-11) or polygenic breccias of metadolerite and metagabbros (10-13 and 18-7) occur. The dolerites are fine-grained $(<0.1-0.5 \mathrm{~mm})$ crystalline rocks with a subophitic texture composed of plagioclase laths $\left(a_{16-84}\right.$ to $\left.a b_{61-39}\right)$, occasional olivine (i.e., olivine $f_{85-86}$ in sample 10-7), interstitial to poikilitic clinopyroxene (wo ${ }_{17} \mathrm{en}_{66} \mathrm{fs}_{17}$ to $\mathrm{wo}_{44} \mathrm{en}_{44} \mathrm{fs}_{12}$ ), and Ti-magnetite. The plagioclase and the clinopyroxene crystals have an average length of $0.2-0.7 \mathrm{~mm}$ and a diameter of $0.1-0.4 \mathrm{~mm}$ respectively. Some samples $(2-1,2-4,2-11$, and 10-7) contain phenocrysts of plagioclase and olivine (or olivine pseudomorphs) and rare chromite grains (sample 2-11). The bulk chemical analyses of the dolerites do not differ from those of the basalts from the Intra-rift ridge (Table 2$)$, and show variable contents in compatible $(\mathrm{Ni}=$ 50-200 ppm) and incompatible $(\mathrm{Zr}=45-160$, and $\mathrm{Y}=25-50$ ppm) elements [Blum, 1991]. Although several dolerites are variably metamorphosed by hydrothermal circulation, their original textures are preserved. The altered samples contain olivine which is generally replaced by yellow-green and yellowbrown smectite $(2-1,2-4,2-11,16-7,20-2$, and 20-13), and veins/veinlets of chlorite/smectite (2-1 and 2-4), actinolite (2$10)$, zeolite (2-3 and 18-7), prehnite (9-11 and 10-13), carbonates (10-13), and quartz (5-1). The metadolerites (2-3, 2-8, 2-10, 5-1, $10-13$, and 18-10) contain a matrix of smectite-chlorite in mixed layers or chlorite-actinolite assemblages and laths of albitized plagioclase. Ti-magnetite is generally preserved, and sphene (210 and 7-3) and secondary pyrite occasionally occur (5-1).

\section{Volcanics}

The volcanics (Table 1 and Figures 2 and 3 ) from the Intrarift ridge are observed at various depths (3000-5000 m) and consist of loosely fragmented material forming talus and breccias (2-15, 9-14, 9-11, 18-14, and 18-17). Fragments of pillow lava with radial jointing and preserved glassy margins as well as hyaloclastites (17-18 and 18-8) were recognized among the talus material (Table 1). Most samples are moderately porphyritic with mainly plagioclase and olivine phenocrysts, which occasionally form aggregates (glomeroporphyric texture). In contrast, highly phyric plagioclase basalts were recovered during the dives on the adjacent Cocos-Nazca ridge system [Constantin et al., 1993]. One sample (9-11) of a picritic basalt with a large amount (> 10\%) of olivine phenocrysts, generally altered into smectite-chlorite mixed-layers, and containing spinel ( $\mathrm{Cr} \# 0.35$ and $\mathrm{Mg \#} \mathrm{0.76)}$ was found. Many samples from the Intrarift ridge were partly altered and contain yellow to reddish-brown $\mathrm{Fe}$ oxyhydroxide and clay minerals replacing the olivine phenocrysts or the mesostasis, or lining vesicle walls $(9-2,10-5,10-8,16-12$, $17-19,18-20,20-8$, and 21-12). Metabasalts (3-11 and 9-4) contain albitized plagioclase microlites and chlorite-smectite mixed layers or yellow to reddish-brown Fe-oxyhydroxide and clay in their mesostasis. Sample 10-1 is made up of albitized plagioclase, actinolite fibers which developed after clinopyroxene, and a chloritized matrix criss-crossed by veinlets of chlorite and quartz throughout (10-1).

Plate 2. Microphotographs of peridotites and gabbros from the Intrarift ridge of the Hess Deep (Table 1 and Figures $1 \mathrm{~b}, 2$, and 3). (a) Undeformed olivine crystals showing protogranular textures in harzburgite (17-9). (b) Werhlite impregnations in harzburgite (17-9); interstitial clinopyroxene has crystallized between olivine grains. (c) Strips of clinopyroxene bounding plagioclase and olivine crystals in the olivine gabbro (9-6). (d) Chromite (dark crystals) concentration in an impregnated dunite (9-7). The plagioclase (white area) are altered into prehnite (brown) and hydrogrossular garnet. Olivine (white) is altered into serpentine and magnetite. (e) Nonfoliated amphibolite (10-14) showing amphiboles (brown and green), albitized plagioclase (white), apatite (euhedral, white), and an ilmenitemagnetite association (dark area). $(f)$ Clinopyroxene exsolution lamellae in orthopyroxene. Interstitial clinopyroxene occurs between the orthopyroxene and olivine in an impregnated harzburgite (17-1). (g) Isotropic gabbro (20-5) showing poickilitic crystals of orthopyroxene including plagioclase laths. $(h)$ Mosaic like aggregates of clinopyroxene and plagioclase in a recrystallized mylonitic gabbro (9-20). 
OMAN

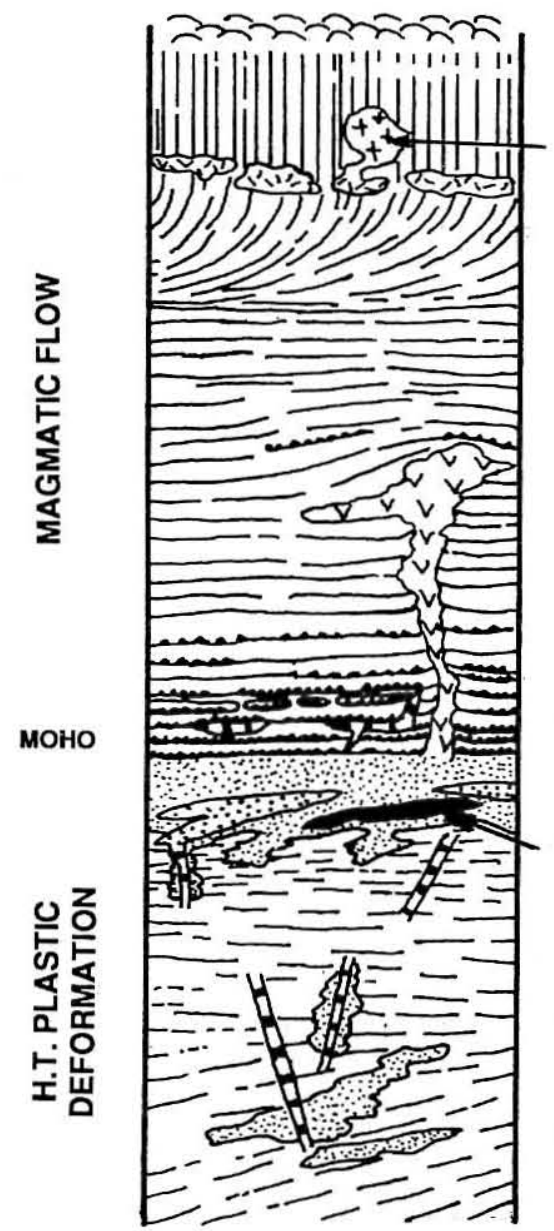

HESS DEEP (INTRA-RIFT-RIDGE)

RECONSTRUCTED

PILlow LaVAS

DIKE COMPLEX

PLAGIOGRANITE INTRUSION

SOTROPIC GABBRO

FOUATED GABBRO

LAYERED GABBRO UNIT

WEHRLITE INTRUSION

GABBROS WITH GRADED BEDDING

WEHRLITE SILLS AND DIKES

GABBRO SILLS

DUNITE \pm IMPREGNATED

CHROMITITE

GABBROS DIKES

PYROXENITE DIKES

DUNITE VEINS IN HARZBURGITES

\begin{tabular}{|c|c|}
\hline PILLOWS and SHEET FLOWS & WEATHERED BASALTS \\
\hline DOLERITES & METABASALTS \\
METADOLERITES
\end{tabular}

Fig. 4. Synthetic log of the Samail ophiolite complex in Oman [after Nicolas et al., 1988] compared to the East Pacific Rise crust and upper mantle exposed in the Hess Deep region. 
Based on the $\mathrm{K} / \mathrm{Ti}$ and $\mathrm{Mg \#}$ variations from microprobe analysis on fresh glassy basalts margins, selected specimens were classified as being depleted (samples 3-10, 10-5, 16-2, and 10-18; $\mathrm{K} / \mathrm{Ti}<0.1)$, transitional $(\mathrm{K} / \mathrm{Ti}=0.1-0.2$; i.e., 18-17B) and undepleted $(\mathrm{K} / \mathrm{Ti}>0.3$; i.e., 17-18, 4-14) rocks (Figure 5). One sample of hyaloclastite (17-18) is composed mainly of unsorted fragments $(<1 \mathrm{~cm}$ in diameter) of partially palagonitized glassy shards which are cemented by Fe-oxyhydroxide products of hydrothermal origin. As indicated from the composition of the freshest glass analyzed, sample 17-18 is made up of compositionally heterogeneous shards going from depleted to transitional and to undepleted types (Figure 5). In addition, these glassy shards are among the most evolved samples with the lowest $\mathrm{Mg \#}$ (0.45-0.55). They are also enriched in $\mathrm{TiO}_{2}(2-3 \mathrm{wt}$ $\%)$ and $\mathrm{FeO}^{*}(11-12 \mathrm{wt} \%)$ and depleted in their $\mathrm{Al}_{2} \mathrm{O}_{3}$ (<14 wt $\%$ ) content when compared to the other basalts except for sample 18-17 which is considered as being a ferrobasalt (Figure 5). Some of the glass shards analyzed from sample 17-18 with the lowest $\mathrm{Mg \#} \mathrm{(0.45)}$ and having a relatively high $\mathrm{SiO}_{2}$ (53 wt \%) content present some affinities with basaltic andesite liquids.
When compared with samples from the EPR axial and off-axial structures at $12^{\circ} 50 \mathrm{~N}, 11^{\circ} 26^{\prime} \mathrm{N}$ [Helimian et al., 1989] and $2^{\circ} 26^{\prime} \mathrm{N}$ [Eissen, 1982], the volcanics from the Hess Deep Intra-rift ridge fall in the same general depleted, transitional, and undepleted basalt fields (Figure 5). Bulk rock and glassy margin analyses of samples from the Cocos-Nazca ridge system show that the rocks are also normally depleted MORBs and fall within the EPR $\left(12^{\circ} 50 \mathrm{~N}-11^{\circ} 30 \mathrm{~N}\right)$ and Hess Deep Intrarift ridge depleted field (Figure 5). They are also comparable to the depleted basalts reported by Shilling et al. [1982] from the Cocos-Nazca ridge. It cannot be determined on the basis of their present compositional variabilities whether the fragmented volcanics encountered on the Intrarift ridge system associated with the other ultramafics and mafics are derived from preexisting outcrops of ancient (1 m.y. old) EPR crust or are the result of recent Cocos-Nazca ridge volcanism. However the exclusively depleted nature and the porphyritic texture (plagioclase phyric) of the Cocos-Nazca ridge samples emphasize the differences with the EPR basalts. In addition, the occurrence of ferrobasalt cannot be a diagnostic criterion for differentiating the EPR volcanics from those of the

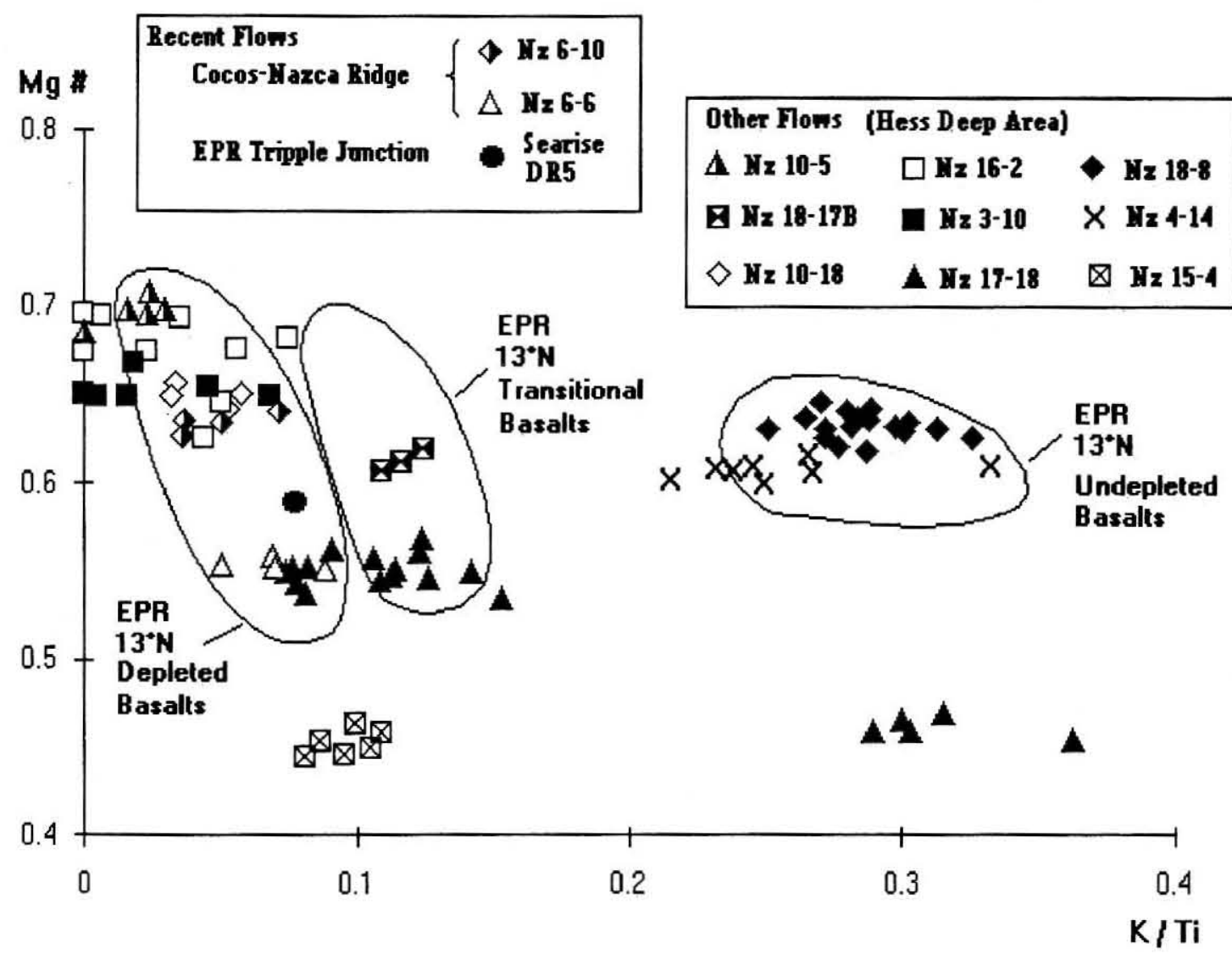

Fig. 5. Mg\# versus $\mathrm{K} / \mathrm{Ti}$ variation diagram of volcanics from the Hess Deep region in the central eastern equatorial region. All the data are microprobe analyses on glass except for sample DR5 from the East Pacific Rise at $2^{\circ} 21^{\prime} \mathrm{N}-102^{\circ} 05^{\prime} \mathrm{W}(3350 \mathrm{~m}$ depth) with data from Eissen [1982] (Figure 1a). The Cocos-Nazca Ridge plagioclase phyric (6-10 and 6-6) and other bulk rock analyses published by Schilling et al. [1982] which were not reported in this study fall in the field of EPR depleted MORBs. Sample 15-4 collected from the westward prolongation of the Cocos-Nazca propagator also consists of depleted and evolved basalts similar to the Cocos-Nazca ridge volcanics. All the samples have a basaltic composition except for the series of glass shards from sample 17-18 with the highest $\mathrm{K} / \mathrm{Ti}$ (0.30) ratios and lowest $\mathrm{Mg \#}(<0.50)$ which consist of basaltic andesite $\left(\mathrm{SiO}_{2}=52-54 \%\right)$. This sample $(17-18)$ is a hyaloclastite composed of several types of glassy shards having variable $\mathrm{K} / \mathrm{Ti}$ ratios (0.7-0.35). The shards of this hyaloclastite consist of basaltic andesite and ferrobasalt glass. Samples 3-10, 10-5, 16-2, and 10-18 are depleted MORBs. Samples 18-8 and 4-14 also representing EPR crust are more enriched in incompatible elements. Sample $18-17$ is a ferrobasalt. The $\mathrm{Mg} \#=\mathrm{Mg}^{2+}\left(\mathrm{Mg}^{2+}+\mathrm{Fe}^{2+}\right)$. $\mathrm{Fe}^{2+}$ obtained from $\mathrm{Fe}_{2} \mathrm{O}_{3}=0.15 \times \mathrm{FeO}$ [Brooks, 1976]. The enclosed fields represent depleted, transitional and undepleted basalts encountered on the EPR at ${ }^{3} 12^{\circ} 50^{\prime} \mathrm{N}$ [Hekinian et al., 1989]. The least evolved samples are represented by the depleted basalts $16-2$ and 10-5 (Table 2). 
Cocos-Nazca ridge, since they are found in association with normal MORBs along various segments of the EPR [i.e., Renard et al., 1985; Morel and Hekinian 1980)].

\section{Mineralogical VARIATIONS}

The mineral compositions are compared to those obtained under the same analytical conditions for samples from the Garrett Transform fault [Hébert et al., 1983; Cannat et al., 1990] where similar rock types, with the exception of isotropic gabbros and dolerites, were recovered.

\section{Pyroxenes}

The $\mathrm{Fe}^{*} /\left(\mathrm{Fe}^{*}+\mathrm{Mg}\right)$ ratios and $\mathrm{CaO}$ contents of the pyroxenes increase progessively from the ultramafics to the olivine gabbro, to the gabbronorite cumulates and to the isotropic gabbros (Figures 6 and 7). Relic orthopyroxene in the harzburgites (samples 17-1, 17-2, 17-3, and 17-16) falls between enstatite and bronzite ( $\mathrm{wo}_{03} \mathrm{en}_{89} \mathrm{fs}_{08}$ ). corresponding to that of the Garrett harzburgites (Figure 6). Some harzburgites (17-1, 17-8, 17-9, and 17-16; Plates $2 a$ and $2 f$ ) contain minor amounts $(<2 \%)$ of undeformed orthopyroxene porphyroclasts $\left(\mathrm{wo}_{03} \mathrm{en}_{89} \mathrm{fs}_{08}\right)$ with exsolution lamellae of clinopyroxene ( $\left.\mathrm{wo}_{43} \mathrm{en}_{52} \mathrm{fs}_{05}\right)$. Clinopyroxene in the harzburgites (Figure 6) shows a lower wollastonite content than that observed in the Garrett's samples (diopside) and corresponds to the intermediate field between diopside and endiopside of the Garrett's impregnated harzburgites [Hébert et al., 1983; Cannat et al., 1990]. The clinopyroxene of the wehrlitic part of the harzburgite sample 179 is slightly enriched in iron $\left(\mathrm{en}_{48} \mathrm{fs}_{09}\right)$, and the orthopyroxene in the harzburgitic part of the sample is a bronzite $\left(\mathrm{en}_{83} \mathrm{fs}_{14}\right)$ which is richer in iron than the Garrett's impregnated harzburgite. The plagioclase-dunite (9-7) also contains minor amounts of "vermicular" (wormlike) clinopyroxene whose bulk compositional field coincides with that of the wehrlite in sample 17-9 (Figure 6). The olivine gabbro cumulates from the Hess Deep have similar orthopyroxene and clinopyroxene compositions ( $\mathrm{wo}_{04} \mathrm{en}_{87} \mathrm{fs}_{9}$ - $\mathrm{wo}_{01}{ }^{\mathrm{en}_{76}} \mathrm{fs}_{23}$ ) to that of the Garrett olivine gabbros and overlap the field of the impregnated harzburgite 17-9 (Figure 6). The isotropic gabbros contain orthopyroxene ( $\mathrm{wo}_{04} \mathrm{en}_{63} \mathrm{fs}_{33}$ ) and clinopyroxene ( $w_{43} \mathrm{en}_{40} \mathrm{fs}_{17}$ ). The field of clinopyroxene composition for the isotropic gabbros overlaps that of the dolerites and the volcanics (with a lower wollastonite content), suggesting a bulk composition close to that of the basaltic liquids, although there was probably a higher crystallization pressure. This field is intermediate between the gabbronorite cumulates from the Hess Deep and the Fe-Ti gabbros from the Garrett fracture zone [Hébert et al., 1983]. The gabbroic mylonites and the relics of clinopyroxene in the amphibolitized metagabbros overlap the field of the gabbronorite cumulates and that of the isotropic gabbros (Figure 8). The $\mathrm{Cr}$ (wt\%) versus $\mathrm{Fe}^{*} /\left(\mathrm{Fe}^{*}+\mathrm{Mg}\right.$ ) diagram shows that the clinopyroxene of the harzburgites and the olivine gabbro cumulates from the Hess Deep, respectively, overlap the fields of the impregnated peridotites and the olivine gabbros from the Garrett fracture zone (Figure 7). Instead, the field of the impregnated peridotites and some of the olivine gabbros from the Hess Deep depart from the nonimpregnated harzburgite and the impregated dunite (9-7) by their higher $\mathrm{Fe}^{*} / \mathrm{Fe}^{*}+\mathrm{Mg}$ which may be the result of pyroxene reequilibration with the melt (Figure 7). In this diagam, the isotropic gabbros, the dolerites and the volcanics have the same trend and fall in the field of lower $\mathrm{Cr}(<$
$0.2 \%$ ) content than the cumulates and the harzburgites which is suggestive of crystal fractionation (Figure 7).

\section{Olivine}

Olivine is generally serpentinized in most of the peridotites and particularly the dunites, but it is better preserved in the impregnated ultramafics and in the olivine gabbro cumulates. The Fo versus $\mathrm{NiO}$ diagram shows that the olivine of the harzburgites (17-1, 17-2, 17-3, and 17-16) has a composition typical of mantle peridotites $\left(>\mathrm{Fo}_{90}\right.$ and $\left.\mathrm{Ni}=3000-4000 \mathrm{ppm}\right)$ and falls in the field of the Garrett's ultramafics (Figure 8). The olivine gabbro cumulates have a larger range of olivine $\left(\mathrm{Fo}_{83-89}\right)$ variation which is suggestive of crystal fractionation, or of slow cooling with partial reequilibration between crystal and interstitial residual liquids. This trend is similar to that of the olivine phenocrysts of the dolerites and the volcanics (Figure 8). The olivine of the dunites and impregnated plagioclase-dunites have an intermediate forsterite composition and overlap the field of the impregnated peridotites from the Garrett transform fault. The olivine of the dunite sample $17-14$ (Figure 8) is slightly more enriched in forsterite $\left(\mathrm{Fo}_{89-90}\right)$ and in its $\mathrm{NiO}$-content (2700-3300 ppm) than the impregnated plagioclase-dunite (sample 9-7; Fo87-89, $\mathrm{NiO}=1900-2400 \mathrm{ppm}$ ). The olivine of the recrystallized mylonitic gabbro (9-17) exhibits the highest depletion in forsterite $\left(\mathrm{FO}_{73}\right)$ and $\mathrm{NiO}$-content of the series. Sample 1-4 was classified as an olivine gabbro cumulate according to its primary texture and mineralogy, but its olivine $\left(\mathrm{Fo}_{91}\right)$ and spinel $(\mathrm{Mg \#} 0.60)$ fall in the field of the ultramafics impregnated with silicate melts (Figures 8 and 9). The wehrlitic olivine of sample 17-9, enriched in NiO-content with respect to the olivine gabbros, is depleted in forsterite when compared to the other ultramafics and departs from the main $\mathrm{NiO}-\mathrm{Fo}$ variation trend defined by the other olivine-bearing rocks (Figure 8). This might suggest a different composition of the mantle source or a more primitive parent for the impregnation liquid, or more likely it indicates different conditions (depth, temperature, etc.) of crystallization. The composition of the olivine of the plagioclase dunites $\left(\mathrm{Fo}_{88-90}, \mathrm{NiO}=2200-3000 \mathrm{ppm}\right)$ is comparable to that of the picritic basalt 9-11 and to the other least evolved basalts and dolerites. The picritic basalt (9-11) having a high bulk NiO content $(516 \mathrm{ppm})$ is believed to be a flow differentiated product which would explain the abnormal accumulation of olivine. Other more evolved basaltic melts (18-20 and 20-11) and a dolerite (10-17) with an intermediate olivine composition (Fo85) and $\mathrm{NiO}(1000-1600 \mathrm{ppm})$ contents are comparable the olivine gabbros (Figure 8).

\section{Spinels and Chromite}

The spinels from the Hess Deep samples as well as those from the Garrett fracture zone [Hébert et al., 1983] have an intermediate composition between picotite and magnesiochromite. In the harzburgites and in the olivine gabbro, the spinels are "holly-leaf" shaped and reddish-brown colored $\mathrm{Cr}$-spinels ( $\mathrm{Cr} \# 0.55$ and $\mathrm{Mg} \#$ 0.60). The spinels of the dunites and the other olivine gabbro cumulates are dark brown to opaque subidiomorphic chromites (Cr\# 0.51-0.55, Mg\# 0.56-0.70). The $\mathrm{Cr} \#$ versus $\mathrm{Mg \#}$ variation diagram shows that most of the samples of ultramafics and olivine gabbros have a composition range of their spinels which overlap the field of the impregnated plagioclase-dunites and the olivine gabbros from the Garrett fracture zone and those from the Oman ophiolites (Figure 9). The harzburgites from the Hess Deep are enriched in their $\mathrm{Mg \# ,} \mathrm{but}$ 


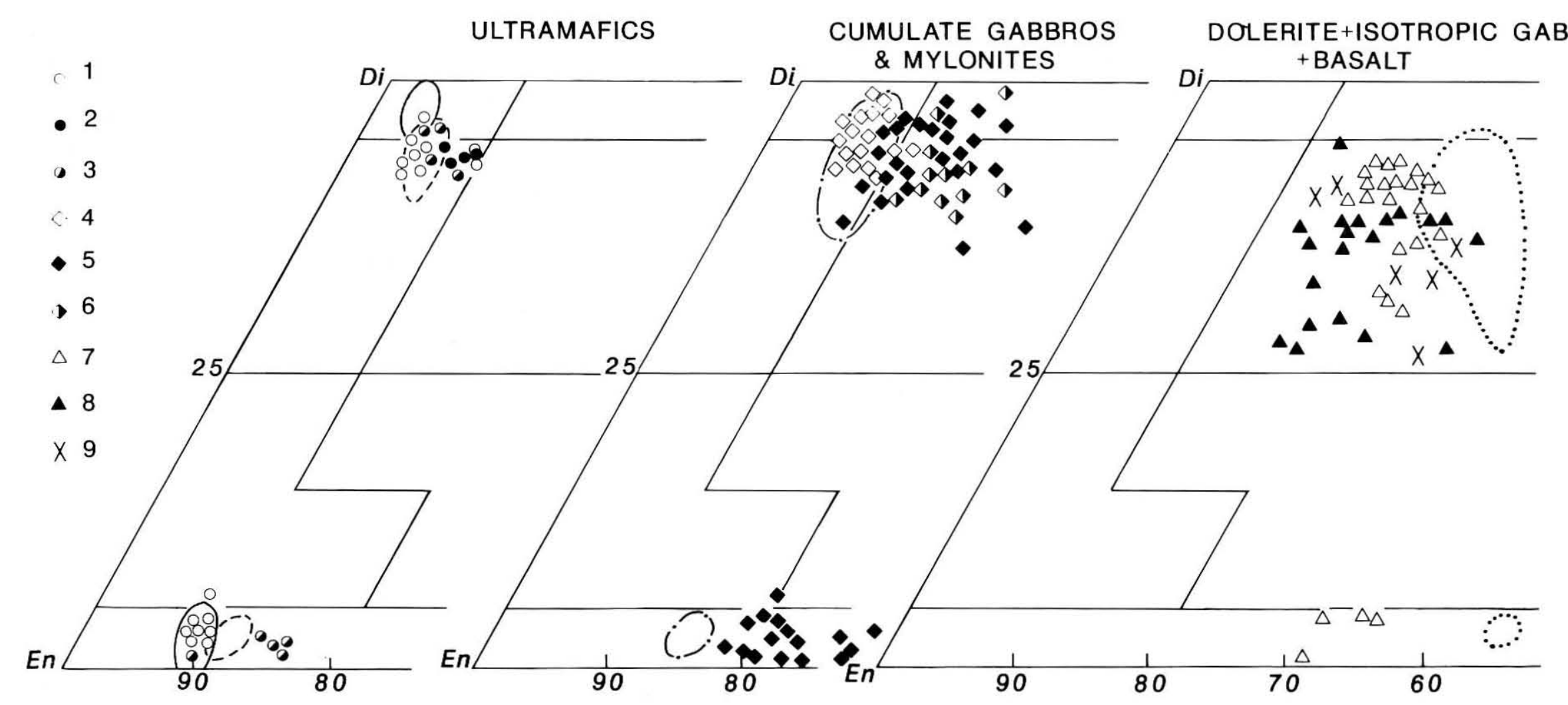

Fig. 6. A wo-en-fs triangular diagram of pyroxenes from the Hess Deep samples: (1) harzburgites (17-1, 17-2, 17-8 and 17-16); (2) troctolite to Chromite-dunite (9-7); (3) harzburgite impregnated by wehrlite (17-9); (4) olivine gabbros (9-10, 9-6, 1-6, 18-3); 5 ) cumulate gabbronorite $(10-9,5-5,5-4) ; 6)$ metagabbros (Nz9-14) and gabbroic mylonites (10-11, 1-5, 18-9, and 9-20); (7) isotropic gabbros (5-2, 5-9, 9-5, 10-16, 5-8); (8) dolerites (10-7, 2-11, 20-2 and 16-10); and (9) basalts $(20-11,20-9,21-12$, and 9-11). The field of samples from the Garrett transform fault are also shown [Hébert et al., 1983]: Solid line, harzburgite; dashed line, pl-dunites; dashed-dotted line, olivine gabbros, and dotted line, Fe-Ti gabbronorites. 


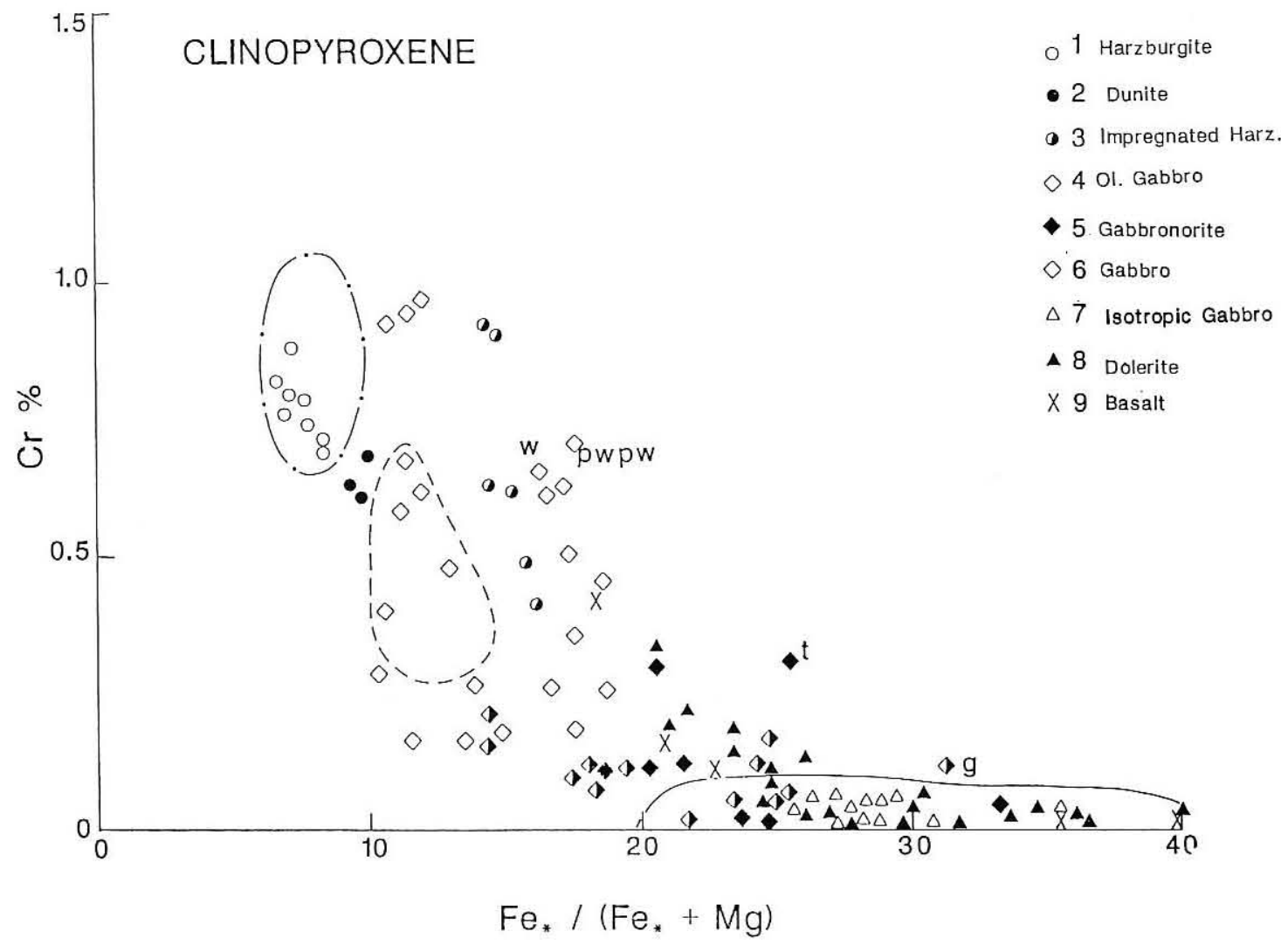

Fig. 7. $\mathrm{Fe}^{*} /\left(\mathrm{Fe}^{*}+\mathrm{Mg}\right)$ versus $\mathrm{Cr}(\mathrm{wi} \%)$ in clinopyroxene of the Hess Deep samples $\left(\mathrm{Fe}^{*}\right.$, total $\left.\mathrm{Fe}\right)$ : $(1)$ harzburgites $(17-1,17-16)$ exsolution lamellae in orthopyroxene; (2) plagioclase-dunite (9-7); (3) harzburgite impregnated by wehrlite (17-9); (4) olivine gabbros (18-3, 9-17, 9-6, 9-16, 1-6, 17-6, and 1-4); (5) gabbronorites (10-9, 5-4, and 5-5); (6) metagabbro (9-14) and gabbroic mylonite (10$11,1-5,18-9$, and 9-20); (7) isotropic gabbros (5-2, 5-9, 9-5, 10-16, and 5-8); (8) dolerites (10-7, 2-11, 20-2, and 16-10); (9) basalts (20-11, 20-9, and 21-12) and picrite (9-11). The rocks from the Garrett Transform area are from Hébert et al. [1983] and are shown by dashed-dotted line, plagioclase dunite and troctolite; dashed line, olivine gabbros; and solid line, Fe-Ti gabbronorites. Impregnated ultramafics (w, wehrlite; pw, plagioclase-wehrlite), troctolite (t), and olivine gabbro (g) from the Samail opiolites [Ernewein et al., 1988 ] are shown.

present higher $\mathrm{Cr} \#$ values than the Garrett's harzburgites, suggesting that they were also partly reequilibrated with melt impregnation or may represent more refractory mantle material. The olivine gabbro (1-4) has a similar spinel composition(Cr\# $0.48, \mathrm{Mg \#} \mathrm{0.64)}$ to that of the harzburgites, suggesting, along with the olivine composition $\left(\mathrm{Fo}_{91}\right)$, that it was probably an ultramafic impregnated by the gabbroic liquid forming most of the sample. The dunite 17-14 and the picritic basalt 9-11 have the lowest $\mathrm{Cr} \#(0.38-0.35)$ of the series and fall in the field of the nonimpregnated ultramafics from the Garrett transform fault. The general trend of the spinel compositional variation in the rocks is suggestive of a melt differentiating during crystal fractionation (Figure 10), with an increase of the $\mathrm{TiO}_{2}$ from the picritic basalt (9-11) and the dunite (17-14) to the olivine gabbro cumulates (i.e., 9-6). The spinel of the non-impregnated harzburgites and the olivine gabbro (1-4) have the lowest $\mathrm{TiO}_{2}$, along with a higher $\mathrm{Cr}_{2} \mathrm{O}_{3}(>40 \%)$ content when compared with other samples. In contrast, the spinels of the plagioclase dunites (9-8 and 9-9) and that of the impregnated troctolite (9-7) with a high $\mathrm{Cr}_{2} \mathrm{O}_{3} \quad(40-42 \%)$ are comparable to the impregnated harzburgite from the Garrett Fracture Zone and the plagioclase wehrlite from the Samail ophhiolite in Oman [Ernewein et al., 1988]. These three samples (9-8, 9-9, and 9-7) depart from the main variability trend (Figure 10), and this might be due to the reequilibrium of their spinel with a melt enriched in $\mathrm{Cr}$.

\section{Plagioclase}

The compositional variation of plagioclase in the Hess Deep suite is shown in Figure 11. The only plagioclase-rich ultramafic is sample 9-7, which contains abundant relics of fresh plagioclase $\left(\operatorname{an}_{87}\right)$, similar to that of the most mafic leucocratic (1-4, 1-6, 9-6, and 9-10) olivine gabbro cumulates (an $84-88)$. The other mesocratic (9-16, 9-17, and 18-3) olivine gabbros have a plagioclase composition between bytownite and labradorite $\left(a_{67-74}\right)$. The isotropic gabbros $\left(a_{50-65}\right)$, the dolerites, and the basalts have a variable anorthite $\left(\mathrm{an}_{50-86}\right)$ of their plagioclase as would be expected during crystal fractionation. Also, the plagioclase composition of the gabbronorite covers the entire range of variation shown by the isotropic gabbros, the dolerites, and the volcanics $\left(\mathrm{an}_{40-84}\right)$. The recrystallized olivine gabbro mylonite (9-20) has a lower anorthite content $\left(a_{51}\right)$. The amphibolitized metagabbros and the amphibolites, however, have a plagioclase composition going from andesite $\left(\mathrm{an}_{40}\right)$ to pure albite (Figure 11).

\section{PETROGENESIS}

\section{Field Relationships and Structural Setting}

Despite a complete cross section of the southern and northern walls of the Intrarift ridge, no coherent organization of the 


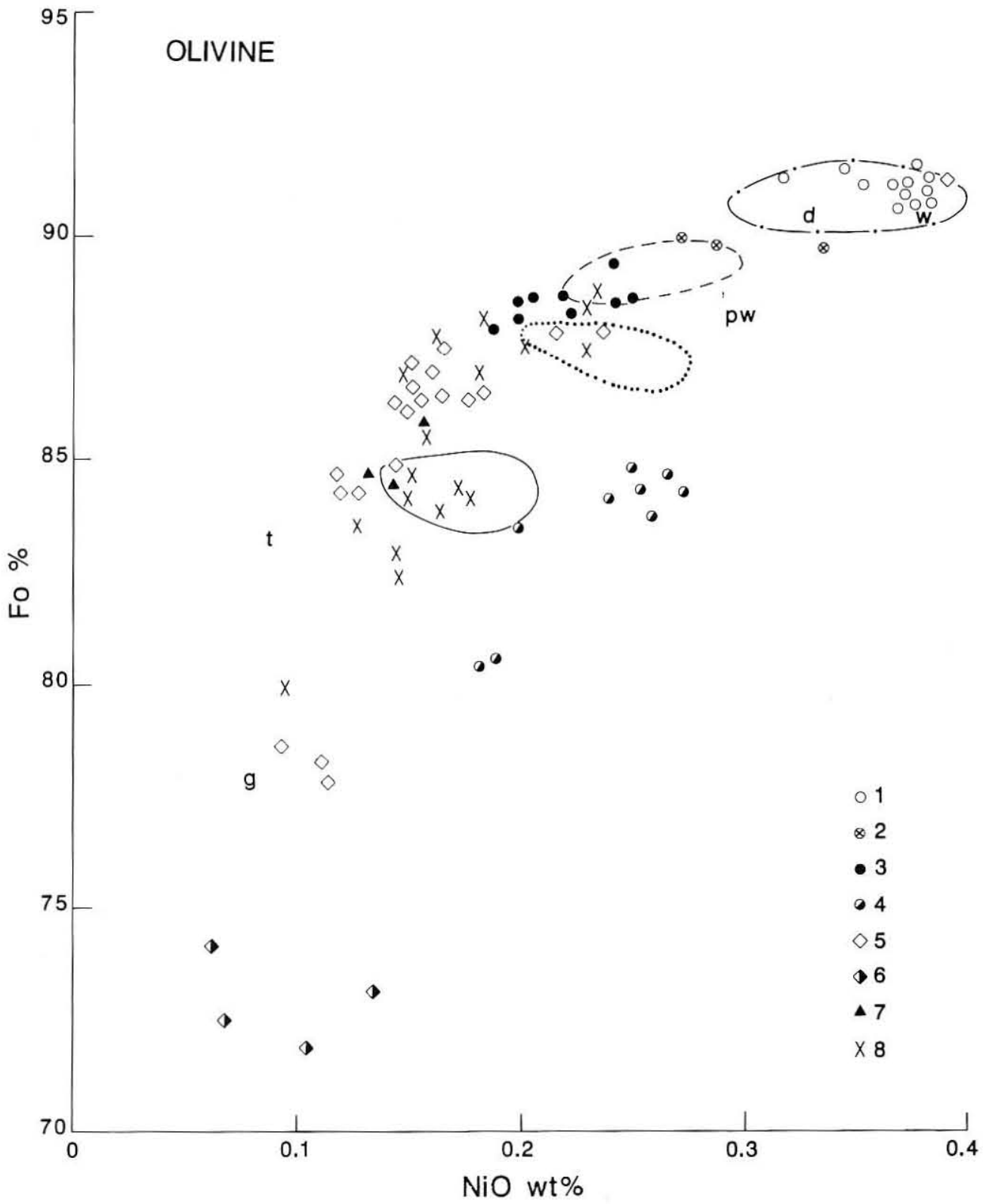

Fig. 8. Fo (\%) versus $\mathrm{NiO}$ (wt \%) in olivine from the Hess Deep samples: (1) harzburgites (17-1, 17-2, 17-3, 17-8, and 14-16); (2) dunite (17-14); (3) troctolite (9-7); (4) harzburgite impregnated by wehrlite (17-9); (5) olivine gabbros (9-10, 9-6, 1-6, and 18-3), troctolite to olivine gabbro (1-4); (6) recrystallized microgabbronorite (9-17); (7) dolerite (10-7); (8) basalt phenocrysts (9-11, 6-10, $10-5,2-9,20-11,18-20$, and 18-17). Also plotted are the fields of the Garrett transform fault samples (EPR $\left.13^{\circ} \mathrm{S}\right)$ [Hébert et al., 1983; Cannat et al., 1990]. Dashed-dotted line, harzburgites; dashed line, impregnated plagioclase-dunites; dotted line, troctolite; solid line, olivine gabbros. In addition, dunite $(\mathrm{d})$, olivine gabbro $(\mathrm{g})$, and impregnated peridotite ( $\mathrm{w}$, wehrlite; pw, plagioclase-wehrlite) from Oman [Ernewein et al., 1988] are reported.

various lithologic units was found (Figures 2, 3, and 12). The presence of talus and isolated massive blocks at various depths suggests that most material has been reworked during tectonic events and by mass wasting (Figures 2 and 3 ). However, there is a slight indication that, west of the Intrarift ridge near $2^{\circ} 15^{\prime} \mathrm{N}$ $101^{\circ} 35^{\prime} \mathrm{W}$, the dunites and the rodingitized gabbros are preferentially concentrated on both sides at a depths between $4900 \mathrm{~m}$ and $5300 \mathrm{~m}$ (Figures 1, 2, 3, and 12). Although basalts and dolerites occur everywhere along the slopes, they are more abundant near the top of the ridge at depths shallower than 3700 $\mathrm{m}$ (Figures 1, 2, 3, 12, and 13). The harzburgites recovered during dive 17 are located $8 \mathrm{~km}$ farther east and occur at shallower depths $(4100-4450 \mathrm{~m})$ than the dunites and the cumulate gabbros (Figure $1 b$ ). In addition a recent dredge haul
DR4 (J. Natland Scripps Institution of Oceanography, personal Communication, 1991) containing serpentinized peridotite and gabbros was also recovered from the southern flank of the Intrarift ridge at 3400-4200 $\mathrm{m}$ depth between dive track 17 to the east and the other dives $(1,2$, and 9$)$ on the western cross section (Figure 2). To correlate the deep seated rock lithology from west to east, a vertical displacement of at least $500 \mathrm{~m}$ is needed. To account for the field observations, this displacement, which might result from shear faulting and/or uplift of a serpentinite sliver, was more prominent west of the studied area (Figures 1, 12, and 13). Intense shearing and crushing is also witnessed locally by the presence of mylonites and cataclastic breccias at various depths (Figures $1 b, 2$ and 3 ). The impregnated ultramafics (wehrlite-bearing harzburgites and plagioclase- 


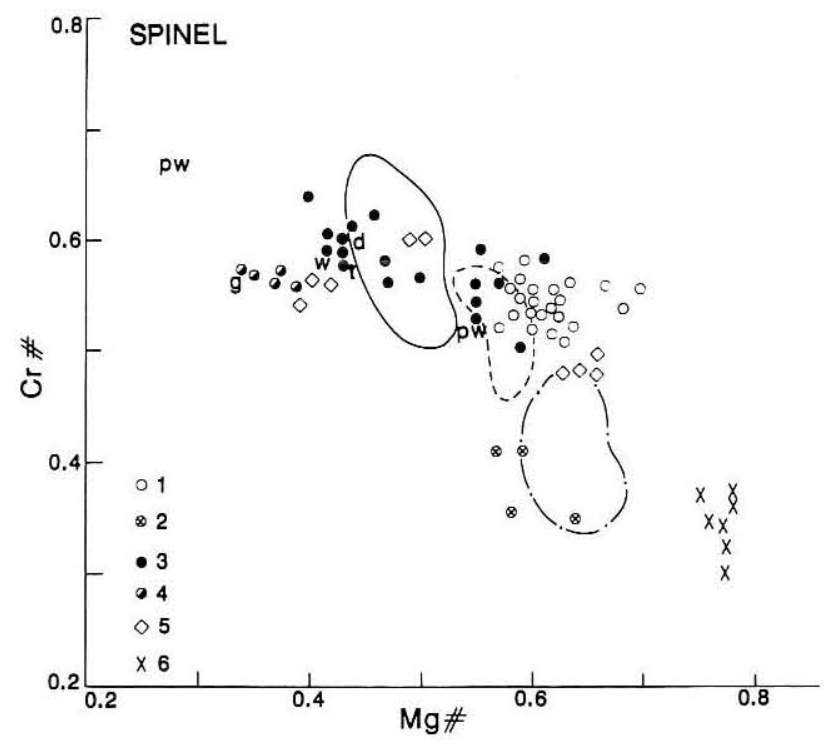

Fig. 9. $\mathrm{Cr} \#\left(\mathrm{Cr}^{3+} /\left(\mathrm{Al}^{3+}+\mathrm{Cr}^{3+}\right)\right.$ versus $\mathrm{Mg} \#\left(\mathrm{Mg}^{2+} /\left(\mathrm{Fe}^{2+}+\mathrm{Mg}^{2+}\right)\right.$ in spinel of the Hess Deep Samples: (1) harzburgites (17-1, 17-2, 17-3, 17-8, 17-1, and 17-16); (2) dunite (17-14); (3) plagioclase-dunites (9-8 and 9-9) and troctolite (9-7); (4) harzburgite impregnated by wehrlite (17-9); (5) olivine gabbros (17-6 and 9-6) olivine gabbro to troctolite (1-4); (6) picritic basalt phenocrysts (9-11). The other fields are samples from the Garrett transform (EPR, $13^{\circ} \mathrm{S}$ ). Dashed-dotted line, harzburgites; dashed line, impregnated harzburgite (plagioclase veinlet); and solid line, plagioclase dunites [after Cannat et al., 1990]. The compositional field of the ultramafics from the Samail ophiolites in Oman is shown [Ernewein et al., 1988]. The symbols are the same as in Figures 7 and 8.

dunites) are likely to represent a refractory uppermost mantle material impregnated by basaltic liquids (Figures 4 and 13) as described in the basal lithological sequences exposed in the Samail ophiolite [Hopson et al., 1981; Reuber, 1988; Juteau et al., 1988; Nicolas et al., 1988]. The olivine gabbro and gabbronorite cumulates are equivalent to the layered and laminated gabbros of Oman (Figure 4), but some of them might have been included in the mantle material. The noncumulate isotropic gabbros occupy the same position with respect to the sheeted dike complex as their counter part (high-level gabbros) found in the ophiolites, as attested to by the contact observed during dive 20 made on the northern wall of the Intrarift ridge (Figure 1a). The rocks were variably altered by hydrothermal fluid circulation which precipitated hydrous silicates, carbonates, and scarce sulfides in major veins and numerous veinlets. Zeolites, albite, smectite, and actinolite are the prominent secondary minerals in metadolerites, metabasalts, isotropic metagabbros, and metagabbronorites. Also, uralitization of pyroxene and albitization of plagioclase is the main metamorphic feature of the gabbros. Serpentinization of the ultramafics provided the Ca-rich solutions responsible for the rodingitization of the most mafic plagioclase-bearing rocks (troctolites, plagioclase-dunites, olivine gabbros) and for the occurrence of various hydrous calc-silicates (prehnite, paragarnet, and hydrogrossular garnet) as replacement products of plagioclase and/or as vein-forming minerals (zeolites, prehnite, and epidote). This is particularly observed in the plagioclase-dunites and the cumulates (olivine gabbros). Carbonates (aragonite) were probably precipitated during a final emplacement of the deep seated rocks onto the seafloor [Bonatti et al., 1974, 1980].

Mantle Impregnations and Cumulate Parental Liquids

The refractory nature of the Hess Deep serpentinized harzburgites is attested to by the high $\mathrm{Mg \#}$, high $\mathrm{NiO}$ and $\mathrm{Cr}_{2} \mathrm{O}_{3}$, and low $\mathrm{TiO}_{2}$ contents of their primary mineral relics (pyroxene, olivine and spinel). One harzburgite specimen (17-9) exhibits textural and mineralogical evidences of werhlitic and local gabbroic impregnation as described in the Samail ophiolite complex in Oman [Hopson et al., 1981; Nicolas et al., 1988; Ernewein et al., 1988]. The presence of undeformed, wormlike clinopyroxene in several other samples (i.e., 17-1, 17-2, 17-8, and 17-12) tends to confirm this opinion. These rocks show mineral compositions which are slightly different from those of other nonimpregnated harzburgites (Figures 7, 9 and 10) and which present affinities with similar rock types recovered from the Garrett transform fault near $13^{\circ} \mathrm{S}$ on the EPR [Cannat et al., 1990] and from the Samail ophiolite [Ernewein et al., 1988]. This compositional difference and the composition of the wehrlitic clinopyroxene which is comparable to that the exsolution lamellae in othopyroxene suggest a partial reequilibration at contact with a basaltic melt. In addition, the spinel composition (Mg\# 0.50-0.65 and $\mathrm{Cr} \#$ 0.45-0.60) falls in an intermediate field between the nonimpregnated harzburgites and the impregnated dunites from the Garrett transform fault, suggesting that reequilibration affected most of the ultramafics (Figure 9). The impregnation and reequilibration of residual

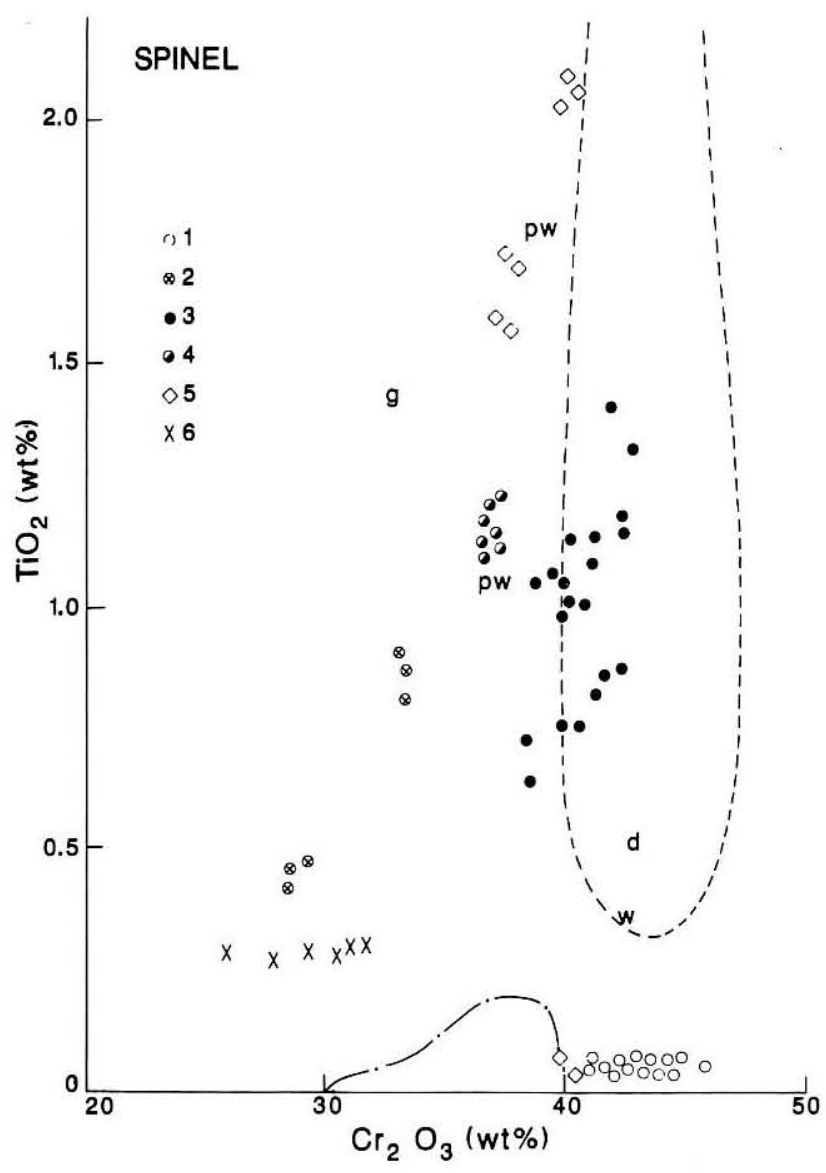

Fig. 10. $\mathrm{TiO}_{2}$ versus $\mathrm{Cr}_{2} \mathrm{O}_{3}$ (wt \%) in spinels and chromites from the Hess Deep samples: (1) harzburgites $(17-1,17-2,17-3,17-5,17-8,17-12$, and 17-16); (2) dunite (17-4); (3) plagioclase-dunite (9-8 and 9-9), and troctolite (9-7); (4) harzburgite impregnated by wehrlite (17-9); (5) olivine gabbros (17-6 and 9-6) to troctolite (1-4); (6) picritic basalt (9-11). The samples from the Garrett FZ (EPR 13ㅇ) [after Hébert et al., 1983; Cannat et al., 1990] are shown as dash-dotted line, harzburgites, and dashed line, plagioclase dunites and troctolites. Dunite (d), wehrlite (w), and plagioclase wehrlite (pw) from the Samail ophiolites are reported [Ernewein et al., 1988]. The symbols are the same as in figures 7 and 8 . 

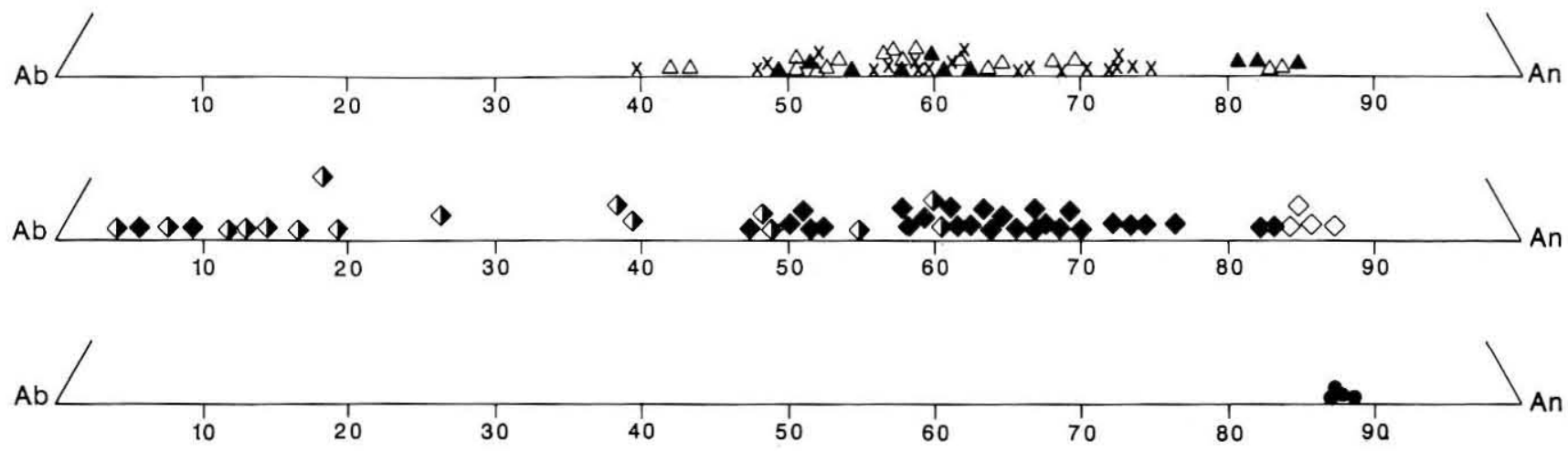

\footnotetext{
$\bullet \quad \diamond^{2} \diamond 3 \quad \diamond^{4} \quad \Delta^{5} \quad \Delta^{6} \quad x^{7}$

Fig. 11. Ab-Or-An ternary diagram of the plagioclase from the Hess Deep samples: (1) troctolite (9-7); (2) olivine gabbros (9-10, 9-6, $1-6$, and 18-3); (3) cumulate gabbronorites (10-9, 5-5, and 5-4); (4) metagabbros and mylonites (10-11, 9-14, 1-5, 18-9, and 9-20); (5) isotropic gabbros (5-2, 5-9, 9-5, 10-16 and 5-8); (6) dolerites (10-7, 2-11, 20-2, and 16-10); (7) extrusive basalts (20-11, 20-9, and 21-12).
}

mantle with basaltic melts are believed to occur in a transition zone located near the crust-mantle boundary (Moho) in the oceanic lithosphere (Figure 4). This reequilibrium phenomenon seems to affect both the ultramafics and the lowermost gabbroic cumulates. The crude layering of alternate plagioclase-rich (gabbroic) levels and dunitic material encountered in sample 9-7 could take place during lateral melt segregation in a partially solidified dunitic mush (Figure 4). The olivine gabbro (1-4) has the texture and the modal composition of a gabbroic cumulate, but the composition of its olivine $(\mathrm{NiO}=3500 \mathrm{ppm})$ and spinel $(\mathrm{Cr} \#<0.50$ and $\mathrm{Mg} \#>0.60)$ is similar to that of a highly residual peridotite (Table 1 and Figures 8 and 9). This sample (1-4) probably represents a large fragment of gabbroic impregnation including some portion of refractory mantle material. As far as the plagioclase and clinopyroxene compositions of the gabbroic material are concerned, these minerals show clear affinities with the most mafic olivine gabbro cumulates (1-6 and 9-6). Whereas the least evolved basalts (16-2 and 10-5) and dolerites (16-4 and 2-11) are near aphyric rocks, they contain a little amount $(<1 \%)$ of $\mathrm{Mg}$-rich olivine $\left(\mathrm{Fo}_{88-90}\right)$ with a higher $\mathrm{NiO}$ content $(1800-2800 \mathrm{ppm})$ than that of the olivine of most the olivine gabbro cumulates (Fig. 10) and other evolved basalts (i.e., $20-11,18-17$ and $18-20$ with $\mathrm{NiO}=1600-$ $2000 \mathrm{ppm}$ and $\left.\mathrm{Fo}_{83-85}\right)$. When assuming equilibrium conditions between olivine and melt in some dolerites (16-4 and 2-11) and basalts (16-2) of the Intrarift ridge having a bulk Ni content of 170-194 ppm, a partition coefficient of 12-13 will yield the calculated Ni content of $175-195 \mathrm{ppm}$. This corresponds to the low-pressure conditions (about 5 kbar [Mysen, 1979]) of partial melting which are appropriate in the context of the EPR primary magmas. The Ni contents of the olivine of the least evolved dolerites and basalts (i.e., 16-2, 10-5 and 16-4) have a similar composition (Figure 8) to that of an impregnated dunite (9-7) and a picritic basalt (9-11).

The least mafic olivine gabbro and gabbronorite cumulates result from a progessive crystal fractionation in the uppermost levels of the mantle and/or on the bottom and the walls of a magma chamber. The noncumulate isotropic gabbros, the dolerites, and the volcanics, having similar compositions, represent the liquid residue left after the partial reequilibration during a magmatic ascent and fractional crystallization. Thus, the noncumulate gabbroic horizon underlying the sheeted dike complex (dive 20) is likely to have formed the walls or the rnof of the magmatic reservoir (Figures 1, 4, and 13). Crystal fractionation responsible for the compositional variabilities is also suggested by the continuous increase in $\mathrm{Zr}$ (20-160 ppm) and $\mathrm{Zr} / \mathrm{Y}$ (1-3) from the gabbroic cumulates, to the isotropic gabbros and the volcanics (Table 2 and Figure 14). Crystal fractionation modeling suggests that about $45-55 \%$ crystallization of plagioclase, olivine, and clinopyroxene (4:1:3) is necessary to obtain the evolved melts with high $\mathrm{Zr}(160 \mathrm{ppm})$ and $\mathrm{Y}(50 \mathrm{ppm})$ contents from a parent having a composition similar to that of sample 16-4. However, the ultramafics fall in a field defined by a low $\mathrm{Zr}(<20 \mathrm{ppm})$ content and variable $\mathrm{Zr} / \mathrm{Y}$ $(>2)$ ratios which are different from that expressed by the crystal fractionation trend (Figure 14). Since $Y$ is more compatible with clinopyroxene than $\mathrm{Zr}$, an increase in the $\mathrm{Zr} / \mathrm{Y}$ ratio for low $\mathrm{Zr}$ values $(<20 \mathrm{ppm}$ ) could be explained by the depletion of pyroxene (residual mantle) and a decrease of this ratio might be the result of reequilibration with impregnating gabbroic melts having variable $(\mathrm{Zr} / \mathrm{Y})$ compositions (Figures 14 and 15). It is likely that the ascent of several successive magmatic pulses might tend to impregnate, to partially reequilibrate, and/or to result in a mixing with other previously trapped liquids in residual mantle harzburgites and lower crustal cumulates (Figures 14 and 15). This implies that heterogeneous mantle sources could also be involved in generating the various partial melts some of which may never attain the surface of the seafloor.

Both the extrusives and the dolerites from the Intra-rift ridge could also be derived from a broad range of primary magmas (depleted, transitional and undepleted MORBs) having a $\mathrm{Mg \#}$ $(0.67-0.70)$ and a forsterite content for their olivine (Fo87-89) which are similar to those of some EPR $12^{\circ} 50 \mathrm{~N}$ basalts [Hekinian et al., 1989]. Available trace element analyses [Blum, 1991] (Table 2) on the dolerites $(9-19,2-11,10-7,16-4,16-10$, 17-11, 18-15, and 18-5) and basalts (9-14, 10-5, and 16-2) show that the $\mathrm{Zr} / \mathrm{Nb}$ ratios $(<60)$ are variable $(\mathrm{Zr}=49-65 \mathrm{ppm}$ and $\mathrm{Nb}$ $<4$ ), and correspond to the entire range of variability of the MORBs (types I and II) as shown by Bryan et al. [1976]. These compositional variabilities are similar to those expressed by the $\mathrm{K} / \mathrm{Ti}$ ratios $(0.2-0.3)$ of the glassy basalts and are useful for determining the various magmatic lineages (Figure 5). A similar diversity of the incompatible element contents in tholeiites from the axial graben of the EPR near $12^{\circ} 50 \mathrm{~N}$ [Prinzhoffer et al., 
DEPTHS IN METRES

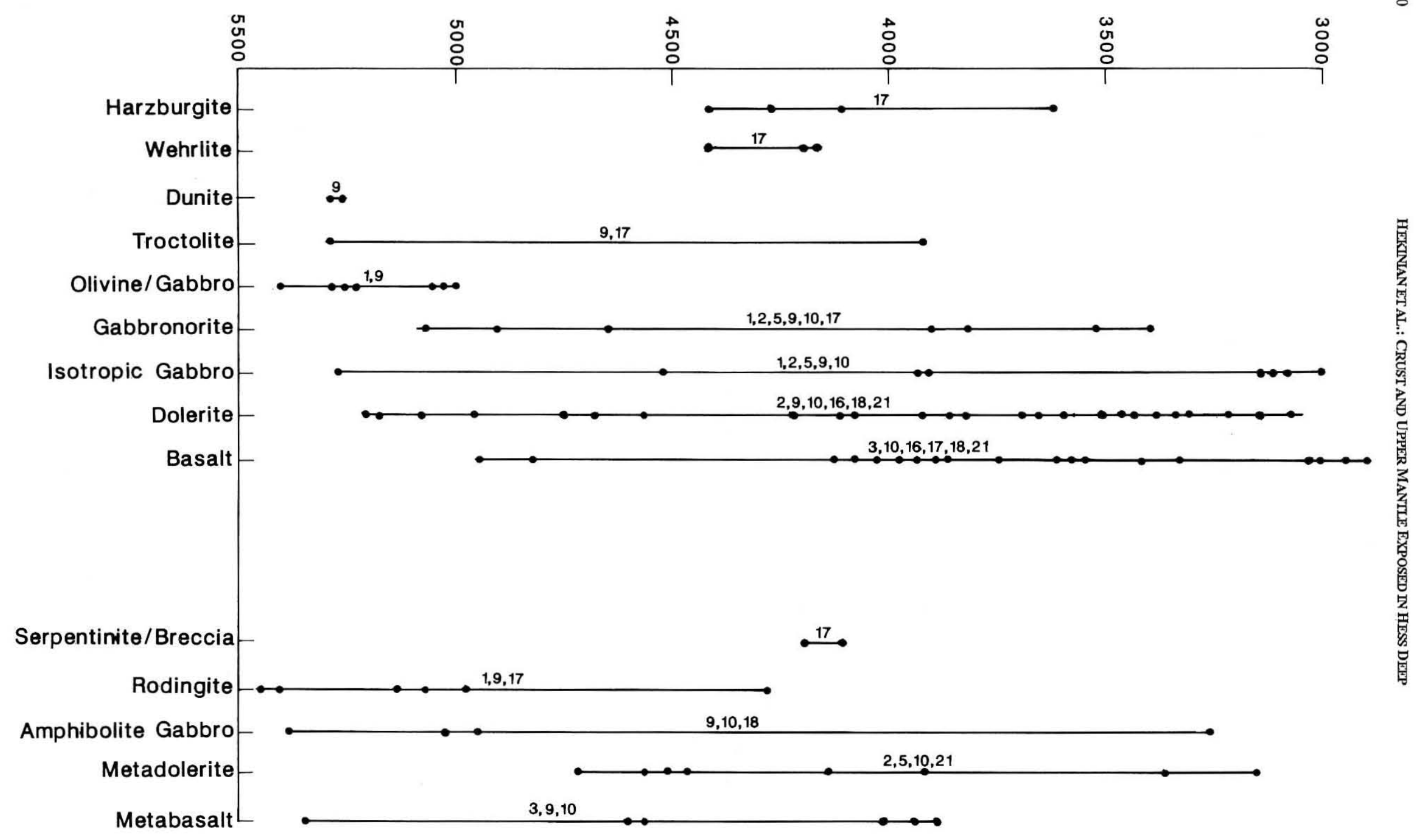

Fig. 12. Depths versus rock types encountered on the Intrarift ridge of the Hess Deep during submersible dives. The dots indicate the sample depths along the dive tracks shown by numbers. The metamorphosed rocks are shown on the right, and their protoliths are on the left of diagram. 


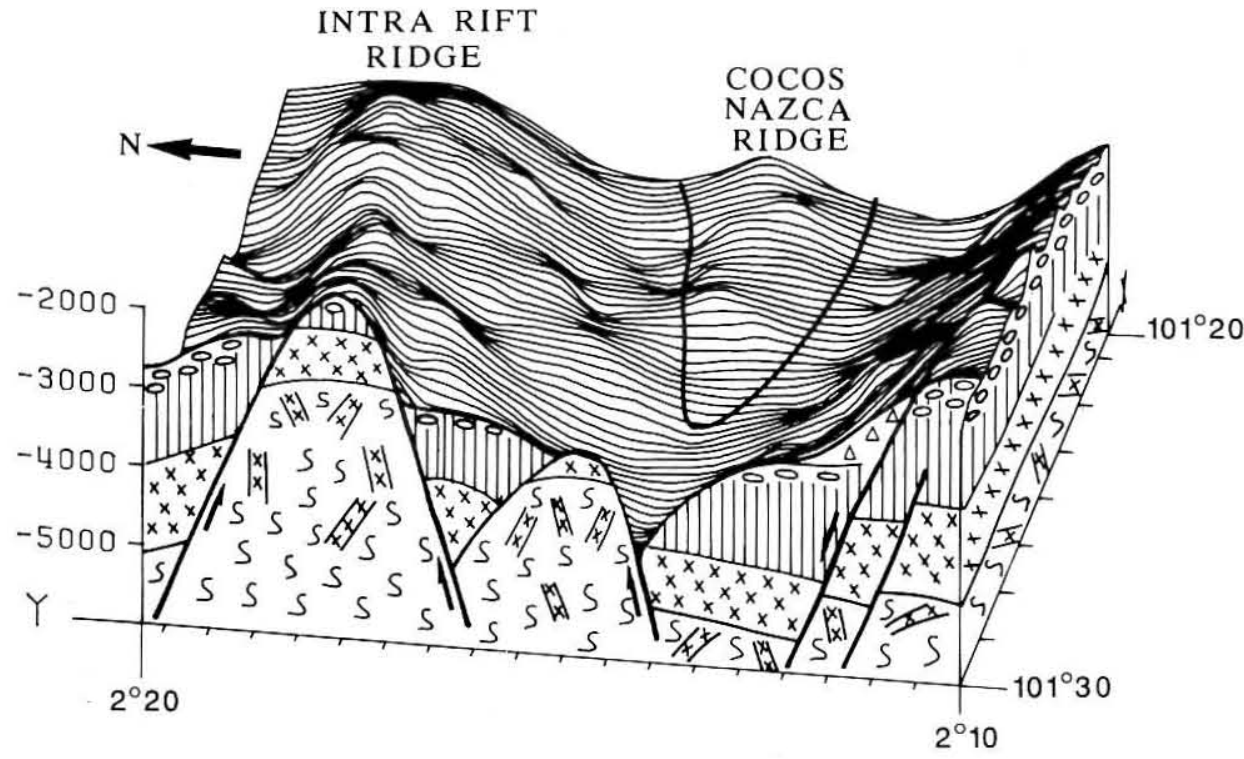

Fig. 13. Block diagram constructed from the bathymetric map shown in Figure $1 \mathrm{~b}$ on which an interpretative sketched geological map is superimposed. The basalts (circles), the dikes (vertical bars), the gabbros (crosses), the serpetinized peridotites (S-shaped symbols), and the associated impregnated liquids (barred crosses) are indicated. It is inferred that tectonic extention coupled with mantle-crust uplift is responsable for the emplacement of the gabbro-peridotite material exposed on the Intrarift Ridge in the Hess Deep.

Hess Deep

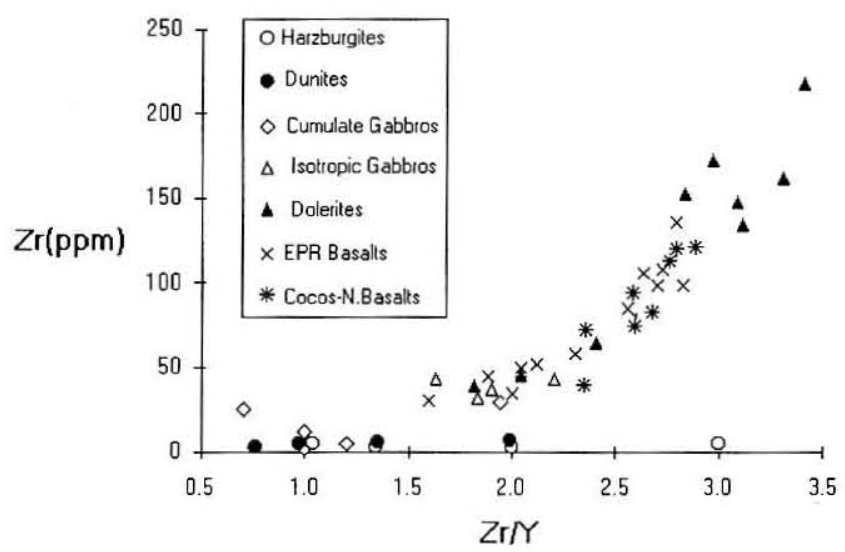

Fig. 14. $\mathrm{Zr}$ versus $\mathrm{Zr} / \mathrm{Y}$ variation diagram of samples from the Hess Deep. The bulk rock analyses of cumulate and noncumulate gabbros and volcanics (dolerites and basalts) show an extended range of $\mathrm{Zr}(20-162 \mathrm{ppm})$ variabilities related to small changes in $\mathrm{Zr} / \mathrm{Y}(<3)$ ratios reflecting crystal fractionation processes. The ultramafics, including the impregnated dunites and harzburgites, have lower $\mathrm{Zr}(<20 \mathrm{ppm})$ contents for a distinctly higher range of $\mathrm{Zr} / \mathrm{Y}(1-5)$ variation which departs from the fractionation trend. This trend is explained by a depletion in clinopyroxene and by the ascent of melts impregnating ultramafics and gabbros. Some cumulate olivine gabbros (9-6, 9-10, and 17-6) fall in this depleted $\mathrm{Zr}$ and high $\mathrm{Zr} / \mathrm{Y}$ field as do some residual harzburgite. Basalts from the Cocos-Nazca ridge (Cocos) and from the Intrarift ridge (IRR) are also shown.

1989; Hekinian et al., 1989] and from the isolated off-axis seamounts [Hekinian et al., 1989] of the same region was attributed to the multi-stage melting of a composite mantle source and periodic extrusion

\section{Temperature of Mineral Formations}

The mineral equilibrium temperatures were calculated using the two pyroxene geothermometers as defined by Kretz [1982]. The harzburgites $(17-1,17-8,17-9$, and 17-16) show similar pyroxene equilibrium temperatures $\left(993^{\circ}-1094^{\circ} \mathrm{C}\right)$ when using clinopyroxene exsolution lamellae and their host orthopyroxene for the calculations. These temperature estimates are clearly indicative of subsolidus recrystallization, but they are comparable to those $\left(1045^{\circ}-1151^{\circ} \mathrm{C}\right)$ obtained when using the interstitial clinopyroxene or the clinopyroxene analyzed in the wehrlitic portion of the impregnated harzburgite (17-9), which show about the same range of composition as the exsolved crystals in each of the respective samples. These results suggest that this refractory mantle material has partly reequilibrated with the basaltic melt impregnation near the liquidus-solidus basalt boundary. The olivine gabbro (1-4), with a comparable olivine and spinel composition to that of the harzburgites, shows similar equilibrium temperature estimates $\left(1039^{\circ}-1049^{\circ} \mathrm{C}\right)$. It is interesting to notice that the temperatures calculated using the most Ca-rich clinopyroxene for the olivine-bearing gabbronorite cumulate 9-16 and the olivine-free gabbronorite cumulates 2-2 and $1-8$ are similar $\left(978^{\circ}-1122^{\circ} \mathrm{C}\right)$. Nevertheless, sample $1-8$ has Ca-poor clinopyroxene $(\mathrm{CaO}=14-18 \%)$ which probably crystallized during advancing fractionation under conditions where the orthopyroxene was no longer stable; the granulation of clinopyroxene due to an annealing of deformed samples, such as 9-20, may result in an enrichment in iron without any significant calcium depletion. The isotropic gabbronorites (20-2, 20-5, and 20-6) have comparable crystallization temperature ranges to those of the cumulates $\left(1026^{\circ}-1170^{\circ} \mathrm{C}\right)$, whereas the isotropic gabbros without orthopyroxene show a clinopyroxene composition which overlaps the dolerite field (lower $\mathrm{CaO}$ and higher $\mathrm{FeO}^{*}$ contents). Keeping in mind the large range in temperature variation observed in a single sample (up to $\pm 40^{\circ} \mathrm{C}$ for the Ca-rich clinopyroxene), one could estimate that the comparable equilibrium temperature of the pyroxene pairs between the impregnated ultramafics, and the cumulate gabbronorites represent the equilibrium condition for the upper mantle material and the parental melt of the cumulates. After cumulate crystallization, the residual melt formed the other isotropic gabbros, the dolerites and the basalts, depending on the 


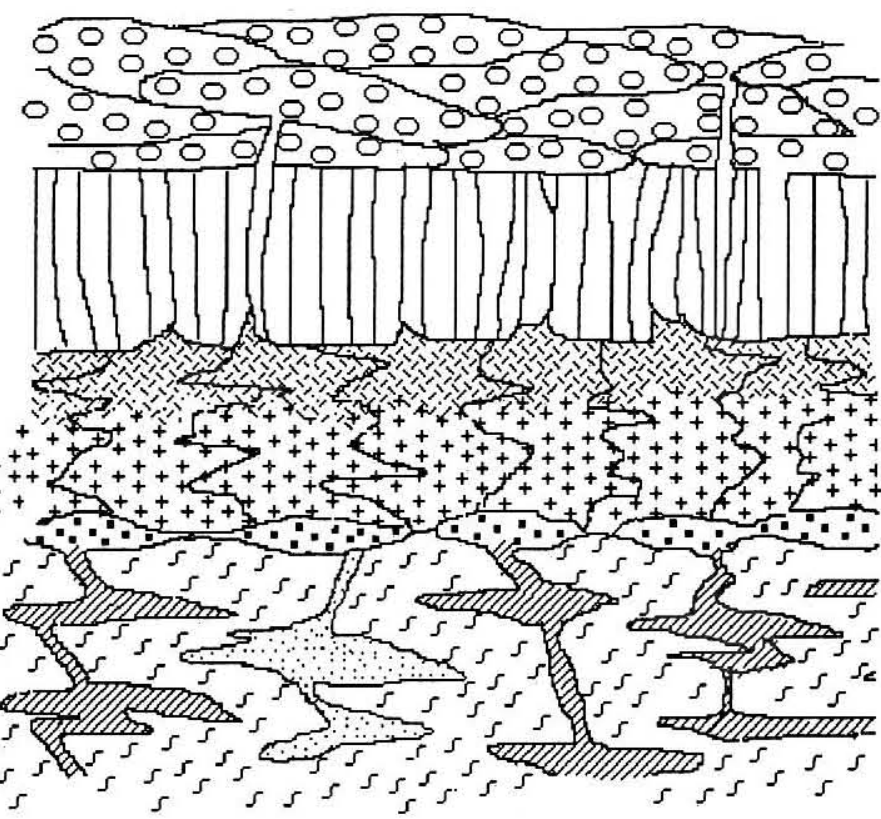

A

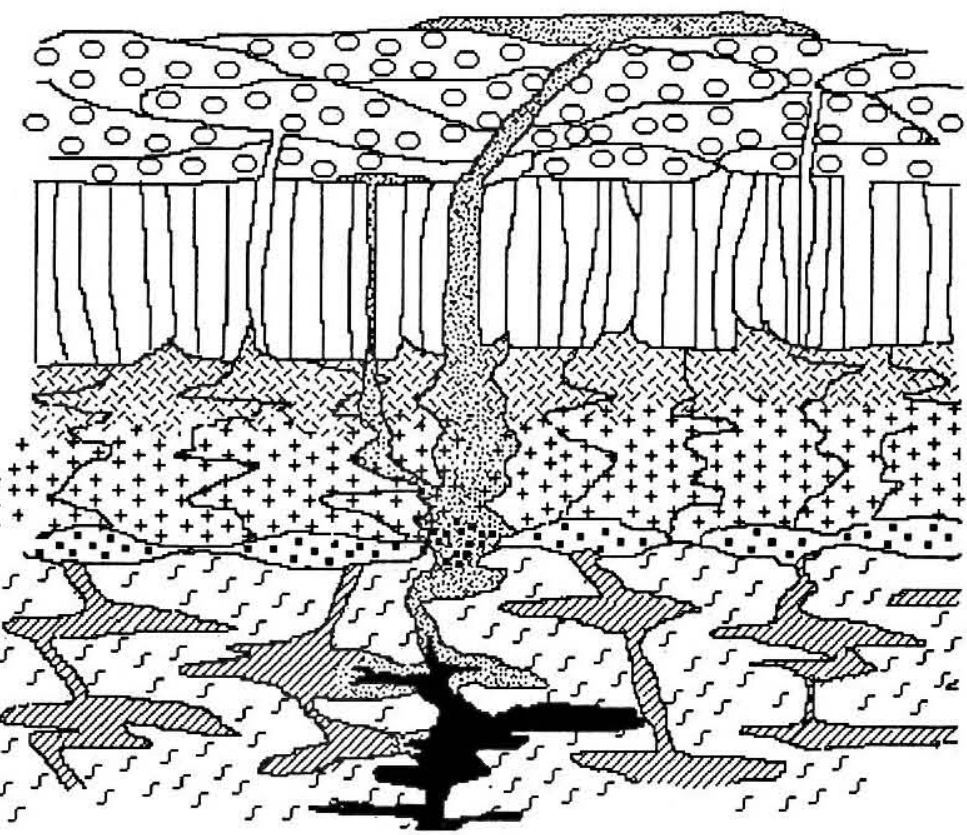

\section{OO Lava Flows \\ [1] Dolerite Dikes

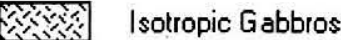 \\ $+_{+}^{+}++$ \\ O... Olivine Gabbro Cumulates and Basal Dunites \\ Residual Harzburgites \\ Wehrlites and Gabbroic Impregnations in peridotite \\ Trapped Magmas [L1) in Harzburgites}

New magmas (L2)

Mixing $(\mathrm{L} 1+\mathrm{L} 2)$

Fig. 15. Schematic representation of upper mantle-crust composition as depicted from mineral analyses of intrusives and extrusives from the Intrarift ridge of the Hess Deep. (a) During ascent toward the surface, several magmatic liquids have impregnated previously formed residual mantle and lower crustal cumulates. (b) Such melts will tend to partially reequilibrate as well as to further contaminate (or mix with) successive upwelling melts derived from partial batch melting.

level of cooling of the magmas. From these temperature ranges and the $\mathrm{Al}_{2} \mathrm{O}_{3}(1-2.5 \%)$ content of the orthopyroxene it is inferred that the reequilibration of the harzburgites took place under low pressure conditions (about $<2 \mathrm{kbar},<6 \mathrm{~km}$ depths) in accordance with the experimental data of Jaques and Green [1980].

\section{CONCLUSIONS}

Diving with the submersible Nautile on the Intrarift ridge region of the Hess Deep near the tip of the Cocos-Nazca ridge has permitied us to collect one of the most complete lithological series of mafic rocks encountered so far in the same area of the ocean floor at $2900-5400 \mathrm{~m}$ depth. The various rock types consist essentially of dislocated material giving rise to talus debris and large (metric size) isolated blocks composed of harzburgites, plagioclase dunites, olivine gabbronorites, gabbronorites, dolerites, and basalts, and their metamorphosed equivalents. Although there is not a typical sequential order for the emplacement of the collected samples, it is observed that the olivine gabbro, the dunites and the rodingites are among the 
samples found in the deepest $(5400-5000 \mathrm{~m})$ part of the Intrarift ridge. The residual mantle harzburgites occurring at depths which are shallower $(3500-4500 \mathrm{~m})$ than the dunites and olivine gabbros along the Intrarift ridge are likely to have been emplaced during tectonic events due to shear faulting with higher uplift components to the west (about $500 \mathrm{~m}$ ). The residual mantle ultramafics and the lower cumulates were impregnated by basaltic melts (Figure 15) with which they partly reequilibrated in the uppermost mantle and/or basal crust (17-9, 17-1, 17-8, 99, and 9-7). Some impregnated melts containing Mg-rich olivines $\left(\mathrm{Fo}_{88-89}\right)$ with $\mathrm{NiO}$ contents of $1800-2800$ ppm are comparable to the least evolved basalts and dolerites encountered on the Intrarift ridge of the Hess Deep.

About $45-55 \%$ crystal fractionation is responsible for the observed compositional variability of the basalts, dolerites, and noncumulate and cumulate gabbros. The volcanics encountered on the Intrarift ridge system in association with the gabbros and dolerites consist of depleted $(\mathrm{K} / \mathrm{Ti}<0.1)$, transitional $(\mathrm{K} / \mathrm{Ti}=$ $0.1-0.25)$, and undepleted $(\mathrm{K} / \mathrm{Ti}>0.25)$ basalts and show similar diversities in their incompatible element chemistry to that of the EPR MORBs near $12^{\circ} 52 \mathrm{~N}$ [Hekinian et al., 1989]. Although the recent volcanics from the Cocos-Nazca ridge are not compositionally different from those of the Intrarift ridge, they are more porphyritic (mainly highly phyric plagioclase basalts), a feature that is not common for intermediate to ultra-fast spreading ridges $(6-16 \mathrm{~cm} / \mathrm{y}$ total rate) as pointed out by Eissen et al. [1981]. Also the Cocos-Nazca basalts studied here consist of essentially depleted MORBs as opposed to the Intrarift ridge samples.

The Fe-oxyhydroxide deposits which are found on the southern flank and on the top of the Intrarift ridge systems are postdepositional to the emplacement of the associated dolerite and basalt-forming breccia and were formed during lowtemperature fluid circulation, possibly related to the emplacement of serpentinized peridotites and gabbros. Hydrothermal and cataclastic metamorphism have affected most of the samples. The metabasalts, metadolerites, and isotropic metagabbros have undergone greenschist $\left(>300^{\circ} \mathrm{C}\right)$ to zeolite $(<$ $200^{\circ} \mathrm{C}$ ) facies metamorphism and late diagenesis during uplift. The serpentinization of the ultramafics and the rodingitization of the gabbroic cumulates and of the plagioclase-rich impregnated rocks took place during the circulation of deep convecting hydrothermal fluids in the mantle-crust boundary regions. This might suggest that the emplacement of the Intrarift ridge was due to tectonic extention coupled with mantle-crust uplift and shear faulting during which thermal and cataclastic metamorphism took place. Hydrothermal metamorphism might have been facilitated by the presence of the Cocos-Nazca propagator which magmatic upwelling could have been a source of heat release.

Acknowledgments. We thank the officers and the crew of the support ship R/V Nadir and the pilots and technicians of the submersible Nautile for their help and expertise. J. Allan, J. Girardeau, R. Hébert, and Y. Niu provided useful comments for the improvement of the manuscipt. H. Puchelt (University of Karlsruhe) kindly gave permission to reproduce part of the Hess Deep Sea Beam survey. The analytical data were obtained using a Camebax MBX microprobe located at IFREMER (Brest) with the help of Marcel Boln. The diving cruise was organized by INSU (Institut National des Sciences de l'Univers) and IPG (Institut de Physique du Globe, Paris, France).

\section{REFERENCES}

Anderson, R.N., and R.K. Nishimori, Gabbro, serpentinite and mafic breccia from the east Pacific, J. Phys. Earth, 27, 467-480, 1979.

Bideau, D., R. Hébert, R. Hekinian, and M. Cannat, Metamorphism of deep seated rocks from the Garrett Ultrafast Transform (East Pacific Rise near $13^{\circ} 25^{\prime}$ S), J. Geophys. Res. 96, 10,079-10,099, 1991.

Blum, N., Structure and composition of oceanic crust and upper mantle exposed in the Hess Deep of the Galapagos microplate (equatorial east Pacific), Ph.D. thesis, 217 pp., Inst. fur Petrograph. and Geochem. Univ. Karlsruhe, Karlsruhe, 1991.

Bonatti, E., J. Honnorez, and G. Ferrara, Ultramafic Rocks: PeridotiteGabbro-Basalt Complex from the equatorial Mid-Atlantic ridge, Philos. Trans. R. Soc. London, Ser. A, 268, 247-256, 1974.

Bonatti, E., J. R. Lawrence R. E. Hamlyn, and D. Breger, Aragonite from deep sea Ultramafic Rocks, Geochem. Cosmochim. Acta, 44, 1207-1214, 1980.

Brooks, C. K., The $\mathrm{Fe}_{2} \mathrm{O}_{3} / \mathrm{FeO}$ ratio of basalt analyses: An appeal for a standardized procedure, Bull. Geol. Soc. Den., 25, 117-120, 1976.

Bryan, W. B., G. Thompson, F. A. Frey, and J. S. Dickey, Inferred Geologic settings and Differentiation in basalts from the Deep-Sea Drilling Porject, J. Geophys. Res., 81, 4285-4304, 1976.

Cannat, M., D. Bideau, and R. Hébert, Plastic deformation and magmatic impregnation in serpentinized ultramafic rocks from the Garrett Transform fault (East Pacific Rise), Earth Planet. Sci. Lett., 101, 216 $232,1990$.

Constantin, M., R. Hekinian D. Ackermand, P. Stoffers and J. Francheteau, Upper mantle and lower crust exposed in the Easter microplate (south Pacific), (abstract), Terra Nova, 5, 184-185, 1993.

Eissen, J. P., Pétrologie comparée de basaltes de différents segments de zones d'accrétion océaniques à taux d'accrétion variés (Mer Rouge, Atlantique Nord, Pacifique), thèse doctorat (3eme cycle), 201 pp, Université Louis Pasteur, Strasbourg, France, 1982.

Ernewein, M., C. Pflumio, and H. Whitechurch, The death of an accretion zone as evidenced by magmatic history of the Samail ophiolite (Oman), Tectonophysics, 151, 247-274, 1988.

Francheteau, J., P. Patriat, J. Segoufin, R. Armijo, M. Doucoures, A. YellesChaouphe, J. Zukin, S. Calmant, D.F. Naar, and R.C. Searle, Pito and Orongo fracture zones: The northern and southern boundaries of the Easter microplate (south east Pacific), Earth Planet Sci. Lett., 89, 363374, 1988.

Francheteau, J., R. Armijo, J.L. Cheminée, R. Hékinian, P. Lonsdale, and N. Blum, 1 MA East Pacific Rise oceanic crust and uppermost mantle exposed by rifting in Hess Deep (equatorial Pacific Ocean), Earth Planet Sci. Lett., 101, 281-295, 1990.

Hébert, R., D. Bideau, and R. Hekinian, Ultramafic and mafic rocks from the Garrett Transform fault near $13^{\circ} 30^{\prime} \mathrm{S}$ on the East Pacific Rise: Igneous petrology, Earth Planet Sci. Lett,. 65, 107-125, 1983.

Hekinian, R., and D. Bideau, Volcanism and mineralization of the Oceanic crust on the East Pacific Rise, in Metallogeny of Basic and Ultrabasic Rocks, edited by J.J. Gallager, R. A. Ixer, C. R. Neary, and H. M. Prichard, pp 1-20, Institution of Mining and Metallurgy, London, 1986.

Hekinian, R., D. Bideau, M. Cannat, J. Francheteau, and R.Hébert, Volcanic activity and crust-mantle exposure in the ultrafast Garrett transform fault near $13^{\circ} 28^{\prime} \mathrm{S}$ in the Pacific, Earth, Planet. Sci. Lett. 108, 259-273, 1992

Hekinian, R., R. Hebert, R Maury, and E.T. Berger, Orthopyroxene-bearing gabbroic xenoliths in basalt from the East Pacific Rise axis near $12^{\circ} 50^{\prime} \mathrm{N}$, Bull. Mineral., 108, 691-698, 1985.

Hekinian, R., G. Thompson, and D. Bideau, Axial and off-axial heterogeneity of basaltic rucks from the East Pacific Rise at $12^{\circ} 35^{\prime} \mathrm{N}$. $12^{\circ} 51^{\prime} \mathrm{N}$ and $11^{\circ} 26^{\prime} \mathrm{N}-11^{\circ} 30^{\prime} \mathrm{N}, J$. Geophys. Res., 94, 17,437-17,463, 1989.

Honnorez, J., and P. Kirst, Petrology of rodingites from the equatorial MidAtlantic fracture zones and their geotectonic significance, Contrib. Mineral. Petrol., 49, 233-257, 1975.

Hopson, C. A., R. Colman, R. T. Gregory, J.S. Palister, and I. H. Bailey, Geological section through the Samail ophiolite along the Muscat-Ibra transect, southeastern Oman Mountain, J. Geophys. Res., 86, 2527-2544, 1981.

Irving, A. J., Petrology and geochemistry of composite ultramafic xenoliths in alkalic basalts and implication for magmatic processes within the mantle, Am. J. Sci., 280, 389-426, 1980.

Jaques, A. J., and D.H. Green, Anhydrous melting of peridotites at $0-15 \mathrm{~kb}$ pressure and the genesis of tholeiitic basalts, Contrib. Mineral. Petrol., $73,287-310,1980$

Juteau, T., M. Ernewein, I. Reuber, H. Whitechurch, and R. Dahl, Duality of magmatism in the plutonic sequence of the Samail Nappe, Oman, Tectonophysics, 151, 107-136, 1988.

Kashintsev, G. L., and D. Frikh-khar, Structure of the oceanic crust in the Eltanin fault zone (Pacific ocean) based on petrographic data, 
Oceanology, 18, 39-42, 1978.

Kashintsev, G. L., M.I. Kuzmin and E.N. Popilov, Composition and structure of the oceanic crust in the vicinity of the Hess Basin (Pacific ocean), Geotectonics 16,512-520, 1982.

Kretz, R., Transfer and exchange equilibria in a portion of the pyroxene quadrilateral as deduced from natural and experimental data, Geochim. Cosmochim. Acta, 46, 411-421, 1982

Lonsdale, P., Structural pattern of the Galapagos microplate and evolution of the Galapagos triple junction, J. Geophys. Res., 93, 13551-13574, 1988.

Morel, J. M., and R. Hekinian, Compositional variation of volcanics along segments of recent spreading sidges, Contrib. Mineral. Petrol., 72, 425$436,1980$.

Murdmaa, I.O., and T.V. Rozanova, Hess Deep bottom sediment, in Geological-Geophysical Research in Southeastern part of the Pacific Ocean, (in Russian), pp. 252-260, Nauk., Moscow, 1976.

Mysen, B. O., Nickel partitioning between olivine and silicate melt: Henry's law revisited, Amer. Minaralogist, 64, 1107-1114, 1979.

Neprochnov, Yu.P., and G.L. Kashintsev, Composition of main crustal layers of the East Pacific Rise. Oceanology, 239, 199-201, 1978. (Translated from Dok. Akad., Nauk SSSR, 239, 199-201, 1978.)

Nicolas, A., I. Reuber, and K. Benn, A new magma chamber model based on structural studies in the Oman ophiolites, Tectonophysics, 151, 87-105, 1988.

Pallister, J. S., and C.A. Hopson, Samail ophiolite plutonic suite: field relations, phase variations, cryptic variations and layering and a model of a spreading ridge magma chamber, J. Geophys. Res, 86, 2593-2644, 1981

Prinzhoffer, A., E. Lewin, and C.J. Allègre, Stochastic melting of the marble cake mantle: Evidence from local study of the East Pacific Rise at $12^{\circ} 35^{\prime} \mathrm{N}$, Earth Planet Sci. Lett., 92, 189-206, 1989.

Renard, V., R. Hékinian, J. Francheteau, R.D. Ballard, and H. Bäcker, Submersible observations at the axis of the ultra-fast spreading East Pacific Rise (173' to $21^{\circ} 30^{\prime}$ S), Earth Planet. Sci. Lett., 75, 339-353, 1985.
Reuber, I., Complexity of the crustal sequence in the northern Oman ophiolite (Fizh and southern Aswad blocks): The effect of early slicing?, Tectonophysics, 151, 137-165, 1988.

Rosanova, T.V. V.A. Drits, and G. L. Kashitshev, Hydrothermal pyroxene amphibole asbestos rocks from the Hess Trench (East Pacific Rise), Lithol. Mineral. Resour., 3, 275-286, 1979.

Rudnik, G.B., Magmatic and metamorphic rocks in Hess Deep, in Geological-Geophysical Researches in the Southeastern part of the Pacific Ocean (in Russian), pp. 116-125, Nauk Moscow, 1976.

Schilling, J.G., R.H. Kingsley, and J.D. Devine, Galapagos hotspotspreading center system, 1, Spatial, petrological and geochemical variations $\left(83^{\circ} \mathrm{W}-101^{\circ} \mathrm{W}\right)$, J.Geophys. Res., 87, 5593-5610, 1982.

Schmitz, W., A. Singer, H. Bäker, and P. Stoffers, Hydrothermal serpentine in a Hess Deep sediment core, Mar. Geol., 46, 17-26, 1982.

Searle, R., and J. Francheteau, Morphology and tectonics of the Galapagos triple junction, Mar. Geophys. Res., 8, 95-129, 1986.

Vanko, D.A., and R. Batiza, Gabbroic rocks from the Mathematician Ridge failed rift, Nature, 300, 5894, 742- 744, 1982.

R. Armijo, J.-L. Cheminée, J. Francheteau, Institut de Physique du Globe (IPG), 4 Place Jussieu, 75252 Paris, France.

D. Bideau and R. Hekinian, IFREMER/Centre de Brest, B.P. 70, 29280 Plouzané, France.

N. Blum, Institute für Petrographie und Geochemie der Universität Karlsruhe, Kaiserstrasse, 12 D 7500, Karlsruhe, Germany.

P. Lonsdale, Scripps Institution of Oceanography, La Jolla, CA 92093.

(Received June 26 1991; revised September 1, 1992; accepted September 4, 1992.) 